\title{
Powikłania infekcyjne w hematologii
}

\author{
Infectious complications in hematology
}

\author{
Anna Czyż \\ Katedra i Klinika Hematologii i Transplantacji Szpiku, \\ Uniwersytet Medyczny im. Karola Marcinkowskiego, Poznań
}

\begin{abstract}
Streszczenie
Zakażenia sa jednymi z najczestszych $i$ najpowazniejszych powiktań $w$ hematologii. W pracy przestawiono epidemiologie zakazen bakteryjnych, grzybiczych i wirusowych u chorych poddanych chemioterapii lub przeszczepieniu krwiotwórczych komórek macierzystych z powodu nowotworów uktadu chtonnego lub krwiotwórczego. Omówiono zasady diagnostyki, profilaktyki oraz leczenia powiktań infekcyjnych na podstawie rekomendacji miedzynarodowych towarzystw i grup ekspertów, ze szczególnym uwzględnieniem zaleceń European Conference on Infections in Leukemia, Infectious Disease Society of America oraz National Comprehensive Cancer Network.
\end{abstract}

Słowa kluczowe: powikłania infekcyjne, chemioterapia, przeszczepienie krwiotwórczych komórek macierzystych, gorączka neutropeniczna, inwazyjne zakażenie grzybicze, zakażenia wirusowe

Hematologia 2015; 6, 2: 136-154

\begin{abstract}
Infectious complications in patients with hematologic malignancies represent one of the most serious problem. This paper reviews the epidemiology of bacterial, fungal and viral infections in hematological patients receiving chemotherapy or undergoing hematopoietic cell transplantation. The principles of diagnosis, prevention and treatment of infectious complications based on the recommendations of international societies and expert groups are discussed with particular emphasis on the guidelines of the European Conference on Infections in Leukemia, the Infectious Disease Society of America and the National Comprehensive Cancer Network.
\end{abstract}

Key words: infectious complications, chemotherapy, hematopoietic stem cell transplantation, febrile neutropenia, invasive fungal infections, viral infections

Hematologia 2015; 6, 2: 136-154

\section{Wprowadzenie}

Powikłania infekcyjne u chorych na schorzenia hematologiczne rozwijają się w wyniku zaburzeń odporności będących skutkiem zarówno samej choroby, jak i jej leczenia. Nasilenie ryzyka różnego typu zakażeń zależy przede wszystkim od rodzaju nowotworu, metod terapii oraz czasu trwania neutropenii indukowanej leczeniem (tab. 1) [1].

Stopień nasilenia neutropenii i czas jej trwania są podstawowymi czynnikami ryzyka rozwoju infekcji u chorych poddawanych chemioterapii. Ryzyko to zwiększają również uszkodzenie błon śluzowych, przebyta splenektomia lub czynnoś-

Adres do korespondencji: Anna Czyż, Katedra i Klinika Hematologii i Transplantacji Szpiku, Uniwersytet Medyczny im. Karola Marcinkowskiego, ul. Szamarzewskiego 84, 60-569 Poznań, e-mail: aczyz@onet.eu 
Tabela 1. Ryzyko powikłań infekcyjnych związane z rodzajem nowotworu hematologicznego i prowadzonym leczeniem (wg National Comprehensive Cancer Network [1])

Table 1. The risk of infectious complications associated with the type of hematologic malignancy and treatment (acc. to the National Comprehensive Cancer Network [1])

\begin{tabular}{ll}
\hline Ryzyko powikłań infekcyjnych & Typ nowotworu, rodzaj leczenia oraz przewidywany okres neutropenii \\
\hline Niskie & Przewidywany okres neutropenii $<7$ dni \\
\hline Pośrednie & Przeszczepienie autologicznych krwiotwórczych komórek macierzystych \\
& Chłoniaki \\
& Szpiczak plazmocytowy \\
& Przewlekła białaczka limfocytowa \\
& Leczenie analogami puryn (fludarabina, kladrybina, klofarabina, nelarabina) \\
& chyzyko wzrasta, jeśli lek jest stosowany w wielolekowych schematach intensywnej \\
& Przewidywany okres neutropenii 7-10 dni \\
& Przeszczepienie allogenicznych krwiotwórczych komórek macierzystych \\
& Ostra białaczka w trakcie chemioterapii indukującej lub konsolidującej remisję \\
Wysokie & Leczenie alemtuzumabem \\
& Choroba przeszczep przeciw gospodarzowi w czasie leczenia kortykosteroidami \\
& W dawce $\geq 20$ mg prednizonu/dobę \\
& Przewidywany okres neutropenii > 10 dni \\
\hline
\end{tabular}

ciowa asplenia oraz zaburzenia odporności komórkowej spowodowane kortykosteroidoterapią lub stosowaniem leków limfocytotoksycznych (alemtuzumab, rytuksymab, analogi puryn, inhibitory proteasomu). Na początku pierwszego epizodu neutropenii dominują zakażenia wywołane bakteriami Gram-dodatnimi. W przypadku przedłużającej się ciężkiej neutropenii oraz $\mathrm{w}$ przebiegu kolejnych jej epizodów wzrasta ryzyko zakażeń spowodowanych szczepami bakterii o oporności wielolekowej (MDR, multidrug resistence), a także ryzyko infekcji grzybiczych i wirusowych. Zakażeniom patogenami wewnątrzkomórkowymi sprzyja upośledzenie immunologicznej odpowiedzi komórkowej. Centralny cewnik żylny (CVC, central venous catheter) może stać się źródłem zakażenia bakteriami Gram-dodatnimi, pałeczkami Gram-ujemnymi lub grzybami $z$ rodzaju Candida $[1,2]$.

Grupa szczególnie narażona na powikłania infekcyjne to chorzy po przeszczepieniu krwiotwórczych komórek macierzystych (HSCT, hematopoietic stem cell transplantation). Ze względu na dominujące zaburzenia immunologiczne i rodzaj występujących zakażeń okres po transplantacji dzieli się na 3 fazy [3]. W 1. fazie, w następstwie ciężkiej neutropenii i uszkodzenia błon śluzowych przewodu pokarmowego, dochodzi do rozwoju zakażeń bakteryjnych i grzybiczych (grzybami z rodzaju Aspergillus, rzadziej Candida) oraz reaktywacji zakażeń herpeswirusami — najczęściej wirusem opryszczki pospolitej (HSV, Herpes simplex virus). W 2. fazie (do 3-4 miesięcy po HSCT), w wyniku zaburzeń ilościowych oraz czynnościowych limfocytów T i B, zwiększa się ryzyko infekcji wirusowych (przede wszystkim cytomegalowirusem [CMV, cytomegalovirus]), inwazyjnej aspergilozy oraz zakażeń wywołanych bakteriami otoczkowymi. Ryzyko to jest najwyższe u chorych po przeszczepieniu allogenicznych krwiotwórczych komórek macierzystych (allo-HSCT, allogeneic $H S C T$ ), którzy są leczeni z powodu choroby przeszczep przeciw gospodarzowi (GvHD, graft versus host disease). W późnej 3. fazie nadal mogą występować zakażenia bakteriami otoczkowymi w wyniku utrzymujących się zaburzeń odpowiedzi humoralnej, a ryzyko zakażeń oportunistycznych wciąż pozostaje wysokie u chorych po allo-HSCT z GvHD.

\section{Zakażenia bakteryjne}

Definicje oraz epidemiologia

i czynniki ryzyka

U większości chorych pierwszym objawem infekcji w przebiegu neutropenii jest gorączka, której zwykle nie towarzyszą miejscowe objawy zakażenia. Gorączkę neutropeniczną (FN, febrile neutropenia) rozpoznaje się u chorych z gorączką lub klinicznymi objawami posocznicy, u których bezwzględna liczba neutrofili jest niższa od $0,5 \mathrm{G} / 1$ 
lub od 1,0 G/1, ale przewiduje się dalszy spadek do $0,5 \mathrm{G} / \mathrm{l}$ w kolejnych 48 godzinach. Do rozpoznania FN upoważnia jednorazowy wzrost temperatury do wartości równej lub wyższej od $38,3^{\circ} \mathrm{C}$ (pomiar $\mathrm{w}$ jamie ustnej) lub utrzymywanie się temperatury $38^{\circ} \mathrm{C}$ lub wyższej przez co najmniej godzinę [2]. Gorączka neutropeniczna występuje u ponad $80 \%$ chorych na nowotwory hematologiczne w przebiegu ciężkiej neutropenii indukowanej chemioterapią (CIN, chemotherapy-induced neutropenia) i jest związana $z$ wysoką śmiertelnością. U około połowy chorych nie udaje się klinicznie udokumentować ogniska infekcji, a wyniki badań mikrobiologicznych pozostają ujemne, co uzasadnia rozpoznanie gorączki nieznanego pochodzenia (FUO, fever of unknown origin). Klinicznie udokumentowane ognisko zakażenia stwierdza się natomiast w $20-30 \%$ epizodów FN (najczęściej na podstawie objawów ze strony przewodu pokarmowego, płuc oraz skóry). Wielokrotnie powtarzane badania mikrobiologiczne pozwalają na wykrycie bakteriemii u 15-30\% chorych [4]. W grupie chorych z udokumentowaną mikrobiologicznie infekcją w 55-60\% przypadków wykrywa się bakterie Gram-dodatnie, wśród których dominują koagulozo-ujemne gronkowce, $\alpha$-hemolizujące paciorkowce, gronkowiec złocisty i enterokoki. Wśród zakażeń bakteriami Gram-ujemnymi dominują zakażenia pałeczkami z rodziny Enterobacteriacae (Escherichia coli i Klebsiella pneumoniae), rodzaju Pseudomonas aeruginosa i Acinetobacter. Rokowanie u chorych, u których stwierdza się bakteriemię, jest gorsze niż w grupie $z$ FUO. Śmiertelność w przebiegu Gram-ujemnych i Gram-dodatnich bakteriemii wynosi, odpowiednio, $18 \%$ i 5\%. W ostatniej dekadzie u chorych $z$ neutropenią stwierdza się znaczny wzrost liczby zakażeń spowodowanych szczepami MDR bakterii Gram-ujemnych [4]. W niektórych ośrodkach hematologicznych odnotowano odwrócenie proporcji zakażeń bakteriami Gram-dodatnimi i Gram-ujemnymi u chorych z neutropenią.

\section{Pierwotna przeciwbakteryjna profilaktyka} antybiotykowa u chorych $\mathrm{z}$ CIN

U wszystkich chorych $z$ ciężką neutropenią zaleca się stosowanie zasad profilaktyki środowiskowej (higiena rąk personelu medycznego, odwrotna izolacja chorych, modyfikacja ich diety, zaopatrzenie sal transplantacyjnych w filtry HEPA [high efficiency particulate air]). Farmakologiczną profilaktykę przeciwbakteryjną zaleca się u chorych, u których ryzyko powikłań infekcyjnych jest pośrednie lub wysokie (tab. 1) [1]. Jako wskazanie do stosowania antybiotykoterapii profilaktycznej można również uznać: wcześniejsze epizody FN, przewlekłe rany, cukrzycę, przeładowanie organizmu żelazem, przewlekłą chorobę płuc, starszy wiek chorego. Najczęściej stosowanymi lekami w profilaktyce farmakologicznej są fluorochinolony (ciprofloksacyna i lewofloksacyna) [2]. Wykazano, że ich stosowanie zmniejsza częstość występowania FN oraz ogólne i związane $z$ zakażeniem ryzyko zgonu [5]. Wybór leku stosowanego w pierwotnej profilaktyce przeciwbakteryjnej powinien uwzględniać lokalną sytuację epidemiologiczną ośrodka. Lewofloksacyna wykazuje mniejszą niż ciprofloksacyna aktywność wobec Pseudomonas aeruginosa. Jej aktywność jest natomiast wysoka wobec paciorkowców i innych bakterii Gram-dodatnich [2].

Inna metoda zapobiegania powikłaniom infekcyjnym w przebiegu CIN to stosowanie czynników stymulujących wzrost kolonii granulocytów (G-SCF, granulocyte-colony stimulating factor) u chorych na nowotwory układu chłonnego, u których szacowane ryzyko wystąpienia FN jest nie mniejsze niż 20\% [2]. Wskazania do stosowania G-CSF oraz antybiotyków w profilaktyce zakażeń bakteryjnych należy rozważać oddzielnie. Nie rozstrzygnięto dotychczas, która ze strategii zapobiegania FN jest bardziej skuteczna ani jaka jest skuteczność jednoczesnego stosowania obu metod prewencji.

\section{Zasady postępowania u chorych}

z podejrzeniem zakażenia $\mathrm{w}$ przebiegu $\mathrm{CIN}$

Gorączkujący chory z neutropenią powinien zostać poddany szczegółowemu badaniu lekarskiemu [1, 2]. Należy pamiętać, że u chorego $z$ rozwijającą się posocznicą w przebiegu zakażeń bakteriami Gram-ujemnymi gorączka może nie wystąpić. Uczucie osłabienia, obniżenie temperatury ciała i/lub ciśnienia tętniczego również powinno nasuwać podejrzenie zakażenia. Bardzo istotne dla dalszego postępowania jest zapoznanie się $z$ wynikami wcześniej wykonanych badań mikrobiologicznych. U chorych z głębokimi zaburzeniami odporności komórkowej i humoralnej, jak również u chorych leczonych kortykosteroidami, często nie stwierdza się objawów ogniskowych infekcji lub manifestacja może być skąpoobjawowa. Badanie lekarskie powinno obejmować wnikliwą ocenę błon śluzowych jamy ustnej, okolic krocza i odbytu oraz okolicy wejścia CVC. Należy wykonać morfologię krwi z komputerową oceną rozmazu, podstawowe badania układu krzepnięcia, badanie ogólne moczu, pomiar aktywności enzymów wątrobowych oraz stężeń kreatyniny, mocznika, elektrolitów, bilirubiny i białka C-reaktywnego. Obowiązkowe jest pobranie materiału biologicznego do badań mi- 
Tabela 2. Ocena ryzyka wystąpienia poważnych powikłań w przebiegu gorączki neutropenicznej (wg Multinational Association for Supportive Care in Cancer [6])

Table 2. Assessment of the risk of serious complications of febrile neutropenia (acc. to the Multinational Association for Supportive Care in Cancer Risk-Index Score [6])

\begin{tabular}{lc}
\hline Charakterystyka objawów & Punktacja \\
\hline Nasilenie objawów choroby: & 5 \\
- brak lub łagodne & 3 \\
- umiarkowane & 0 \\
- ciężkie & 5 \\
Skurczowe ciśnienie tętnicze > 90 mm Hg & 4 \\
Brak objawów przewlekłej obturacyjnej choroby płuc & 4 \\
Nowotwór lity & 4 \\
Chłoniak bez poprzedzającej infekcji grzybiczej w wywiadzie & 3 \\
Brak cech odwodnienia wymagającego dożylnego podawania płynów & 3 \\
Chorzy niehospitalizowani w chwili pojawienia się gorączki neutropenicznej & 2 \\
Wiek < 60 lat & 4 \\
\hline
\end{tabular}

krobiologicznych. Zaleca się przynajmniej 2-krotne wykonanie posiewów krwi pobranej z żyły obwodowej, a u chorych z CVC - jednocześnie posiewów krwi pobranej oddzielnie $z$ każdego kanału cewnika. U chorych $z$ objawami ogniskowymi infekcji należy pobrać dodatkowo materiał $z$ odpowiedniej do objawów klinicznych okolicy (np. próbki stolca lub plwociny, wymazu ze zmian skórnych w okolicy wejścia CVC lub $z$ jamy ustnej) oraz wykonać badania obrazowe (klatki piersiowej u chorych $z$ podejrzeniem zapalenia płuc, jamy brzusznej $\mathrm{u}$ chorych $\mathrm{z}$ bólami brzucha lub innymi objawami ze strony przewodu pokarmowego) [1,2].

\section{Ocena ryzyka wystąpienia powikłań} w przebiegu FN

Ocena ryzyka wystąpienia poważnych powikłań w przebiegu FN jest niezbędna do ustalenia konieczności hospitalizacji chorego oraz wyboru sposobu i czasu trwania empirycznej antybiotykoterapii. Do grupy wysokiego ryzyka zalicza się chorych z liczbą neutrofilów równą lub niższą od $0,1 \mathrm{G} / 1$, jeżeli przewidywany okres neutropenii przekracza 7 dni, a także chorych na ostre białaczki lub intensywnie leczonych ( $\mathrm{w}$ tym poddanych HSCT) $[1,2]$. Ryzyko ciężkich powikłań jest wysokie również u chorych odwodnionych, $z$ zapaleniem płuc, bólem w obrębie jamy brzusznej, biegunką, wymiotami, zaburzeniami neurologicznymi lub objawami infekcji związanej z CVC. W celu przeprowadzenia ścisłej oceny ryzyka powikłań i zgonu w przebiegu FN zaleca się wykorzystanie wskaźnika MASCC (Multinational Association for Supportive Care in Cancer) (tab. 2) [2, 6]. Wartość wskaźnika poniżej 21 wskazuje na wysokie ryzyko ciężkich powikłań, natomiast chorzy $z$ wartością 21 lub wyższą są zaliczani do grupy niskiego ryzyka.

Antybiotykoterapia empiryczna w grupie chorych cechujących się niskim ryzykiem poważnych powikłań w przebiegu FN

Większość chorych stabilnych hemodynamicznie, bez poważnych schorzeń wspólistniejących, u których przewiduje się powrót liczby neutrofilów do normy w okresie 7 dni, zalicza się do grupy niskiego ryzyka powikłań w przebiegu FN. Wskazana jest wówczas antybiotykoterapia doustna fluorochinolonem i amoksycyliną $z$ kwasem klawulonowym [1, 2]. Fluorochinolonu nie zaleca się, jeśli stosowano go w profilaktyce przeciwbakteryjnej. Doustna antybiotykoterapia empiryczna może być prowadzona w warunkach domowych u wybranych chorych $z$ grupy niskiego ryzyka po uwzględnieniu czynników socjalnych (np. możliwość szybkiego transportu do szpitala). U chorych, u których po 2-4 dniach doustnej antybiotykoterapii gorączka nie ustąpiła, należy rozważyć zastosowanie dożylne antybiotyków w warunkach szpitalnych.

Antybiotykoterapia empiryczna w grupie chorych obciążonych wysokim ryzykiem poważnych powikłań w przebiegu FN

Chorzy z FN obciążeni wysokim ryzykiem ciężkich powikłań powinni być leczeni dożylną antybiotykoterapią prowadzoną w szpitalu. Zgodnie $z$ rekomendacjami w I linii leczenia FN zaleca się monoterapię antybiotykiem $\beta$-laktamowym o szerokim spektrum działania wykazującym aktywność 


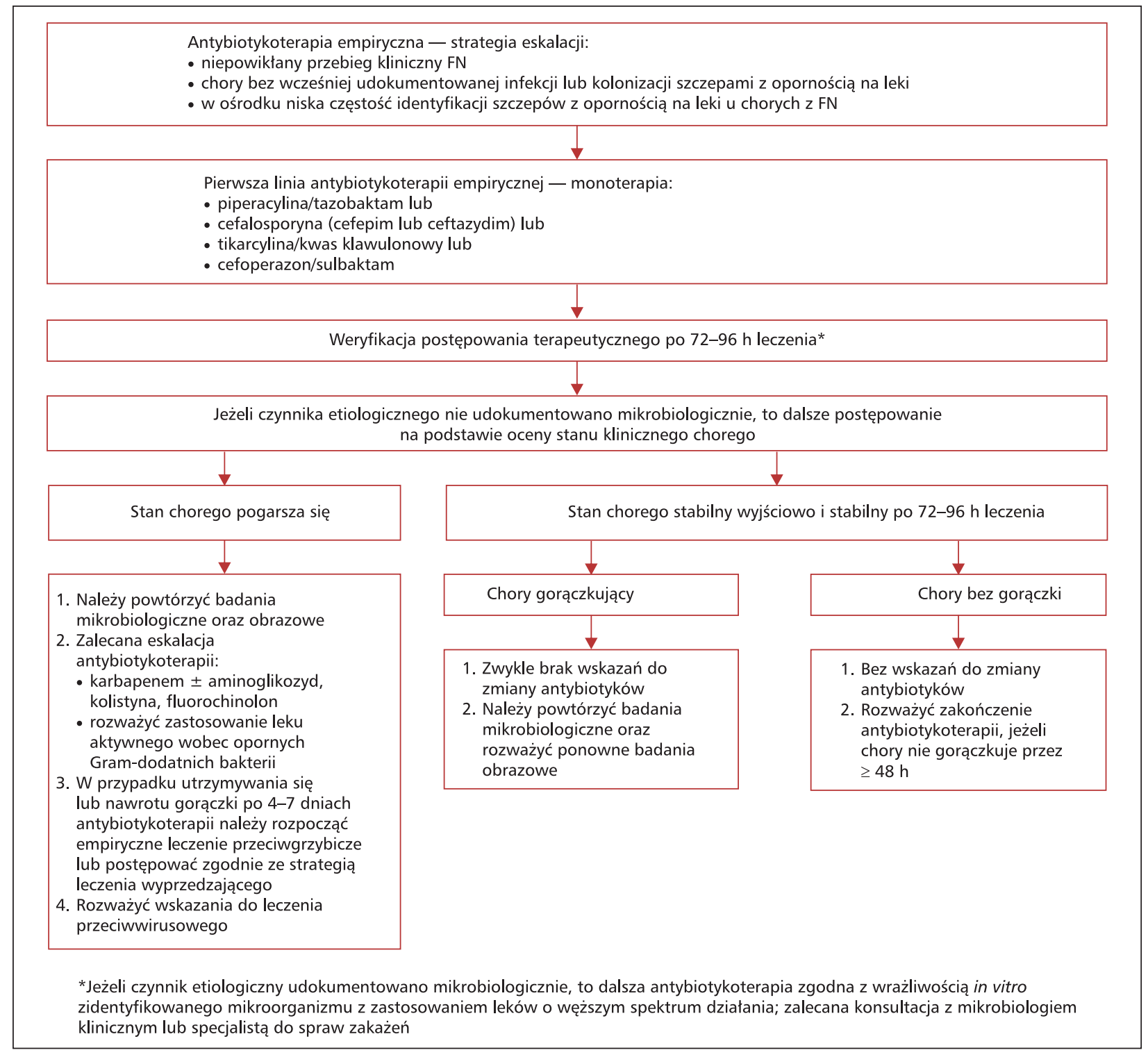

Rycina 1. Zasady strategii „eskalacji” antybiotykoterapii empirycznej (na podstawie zaleceń European Conference on Infections in Leukemia oraz Infectious Disease Society of America [2, 7]); FN - gorączka neutropeniczna

Figure 1. Strategy of "escalation" approach in empiric antibiotic therapy (based on the recommendations of the European Conference on Infections in Leukemia and the Infectious Disease Society of America [2, 7]); FN — febrile neutropenia

wobec Pseudomonas aeruginosa $[1,2,7]$. Do zalecanych antybiotyków zalicza się piperacylinę/tazobaktam, karbapenemy (imipenem/cilastatyna lub meropenem), cefalosporyny (cefepim lub ceftazydym), tikarcylinę/kwas klawulonowy lub cefoperazon/sulbaktam. Antybiotyki te obejmują swoim spektrum większość bakterii Gram-ujemnych $z$ rodziny Enterobacteriace oraz rodzaju Pseudomonas aeruginosa, $z$ wyjątkiem patogenów wytwarzających $\beta$-laktamazę o rozszerzonym profilu substratowym (ESBL, extended-spectrum $\beta$-lactamase) lub innych szczepów MDR. U chorych stabilnych klinicznie, u których nie stwierdza się zwiększonego ryzyka zakażenia szczepami MDR, zaleca się ograniczenie stosowania karbapenemów w terapii I linii. Jeżeli stan chorego nie ulega poprawie po 3-4 dniach monoterapii, to stosowany dotychczas lek należy zastąpić karbapenemem lub zastosować antybiotykoterapię skojarzoną, której spektrum działania obejmie szczepy MDR (,eskalacja” terapii). Zasady strategii „eskalacji” antybiotykoterapii empirycznej przedstawiono na rycinie $1[2,7]$.

Zastosowanie w I linii karbapenemu lub skojarzenie antybiotyku $\beta$-laktamowego aktywnego wo- 
bec Pseudomonas aeruginosa $\mathrm{z}$ aminoglikozydem, kolistyną lub flurochinolonem należy rozważyć u chorych w ciężkim stanie i z powikłanym przebiegiem FN (np. niedociśnienie tętnicze, zapaleniem płuc) oraz w przypadku zwiększonego ryzyka zakażenia szczepami MDR [2, 7]. Przyjmuje się, że ryzyko to jest zwiększone $u$ chorych $z$ wcześniej udokumentowaną mikrobiologicznie infekcją lub kolonizacją wymienionymi wyżej drobnoustrojami oraz w ośrodkach onkohematologicznych, w których częstość identyfikacji szczepów MDR u chorych $z$ FN pozostaje wysoka. Podstawą powyższej strategii jest stosowanie antybiotyków o bardzo szerokim spektrum działania już w I linii leczenia i wymaga ponownej modyfikacji po 72-96 godzinach leczenia w celu rozważenia ograniczenia spektrum (,deeskalacji”) prowadzonej antybiotykoterapii. Zasady strategii „deeskalacji” antybiotykoterapii empirycznej przedstawiono w tabeli $3[2,7]$.

Uzasadnieniem dla modyfikacji antybiotykoterapii empirycznej I linii może być również kliniczne podejrzenie ogniska zakażenia w obrębie jamy brzusznej, zapalenia płuc lub infekcji odcewnikowej (CRI, catheter-related infection) $[1,2]$. W tych sytuacjach zaleca się modyfikacje antybiotykoterapii empirycznej, które obejmują:

- u chorych z klinicznymi objawami zakażenia w obrębie jamy brzusznej lub miednicy — włączenie dodatkowo metronidazolu;

- $\mathrm{u}$ chorych $\mathrm{z}$ biegunką:

- wykonanie badania w kierunku zakażenia Clostridium difficile i w przypadku podejrzenia wymienionego zakażenia włączenie metronidazolu; w przypadku potwierdzenia zakażenia i ciężkiego przebiegu —rozważenie wskazania do zastosowania wankomycyny doustnie (monoterapia lub w skojarzeniu $z$ metronidazolem) lub fidaksomycyny,

- w przypadku podejrzenia neutropenicznego zapalenia jelit po wykluczeniu zakażenia Clostridium difficile zastosowanie antybiotykoterapii skojarzonej o szerokim spektrum działania obejmującym szczepy MDR;

- u chorych na zapalenie płuc - rozważenie zastosowania dodatkowo antybiotyku makrolidowego aktywnego wobec atypowych mikroorganizmów, a w przypadku podejrzenia infekcji Pneumocystis jiroveci (tachypnoe, obniżona saturacja tlenem krwi tętniczej), której ryzyko zwiększa wcześniejsze leczenie kortykosteroidami lub lekami immunosupresyjnymi, leczenie dużymi dawkami kotrimoksazolu;
- $\quad \mathrm{u}$ chorych $\mathrm{z}$ podejrzeniem CRI - wykonanie posiewów krwi pobranej z żyły obwodowej i krwi pobranej z CVC w celu dokonania pomiaru DTP (ang. differential-time-to-positivity); wartość DTP wynosząca 2 godziny lub więcej jest wysoce specyficznym i czułym wskaźnikiem bakteriemii odcewnikowej; podejrzenie CRI stanowi wskazanie do zastosowania wankomycyny lub teikoplainy oraz rozważenia usunięcia cewnika; $u$ chorych stabilnych klinicznie cewnik nie powinien być usuwany, jeżeli nie uzyskano potwierdzenia mikrobiologicznego CRI; w przypadku udokumentowania infekcji koagulozo-ujemnymi gronkowcami u chorych stabilnych cewnik można pozostawić; CRI spowodowane przez gronkowca złocistego, Pseudomonas aeruginosa, grzyby lub mykobakterie stanowi wskazanie do usunięcia cewnika i leczenie celowanego przez nie mniej niż 14 dni; cewnik powinien być równiė usunięty w przypadku objawów zakażenia okolicy wejścia lub kanału cewnika, posocznicy $z$ objawami niestabilności hemodynamicznej, zapalenia wsierdzia oraz utrzymującej się bakteriemii przez 72 godziny lub dłużej mimo właściwego leczenia.

Dalsza modyfikacja empirycznej antybiotykoterapii powinna być prowadzona na podstawie codziennej oceny stanu klinicznego chorego oraz laboratoryjnej oceny czynności układu krwiotwórczego, nerek i innych narządów. Jeżeli nie zidentyfikowano źródła infekcji, a chory nadal gorączkuje, to należy powtarzać badania mikrobiologiczne krwi oraz materiału biologicznego pobieranego $z$ miejsc podejrzanych o zakażenie, a także wykonać ponowne badania obrazowe. U chorych $z$ bólem brzucha i/lub biegunką należy wykonać tomografię komputerową (CT, computed tomography) jamy brzusznej w celu poszukiwania radiologicznych objawów neutropenicznego zapalenia jelit (pogrubienie ścian jelita do 4-5 mm, masa patologiczna lub gaz $\mathrm{w}$ ścianie jelita); CT klatki piersiowej i zatok może wykazać zmiany spotykane w inwazyjnej grzybicy. Należy rozważyć także nieinfekcyjną przyczynę gorączki (np. zakrzepica żył głębokich lub resorpcja krwi $z$ dużego krwiaka). Jednocześnie należy wykonać badania mikrobiologiczne w celu wykrycia infekcji wirusowej lub grzybiczej (seryjne oznaczenie galaktomannanu [GM] lub $\beta$-D-glukanu). U chorych $z$ utrzymującą się lub nawracającą gorączką po 4-7 dniach leczenia antybiotykami o szerokim spektrum działania, u których nie ustalono czynnika etiologicznego, należy rozpocząc empiryczne leczenie przeciwgrzybicze lub postępować zgodnie 
Tabela 3. Zasady strategii „deeskalacji” antybiotykoterapii empirycznej (na podstawie zaleceń European Conference on Infections in Leukemia oraz Infectious Disease Society of America [2, 7])

Table 3. Strategy of "de-escalation" approach in empiric antibiotic therapy (based on the recommendations of the European Conference on Infections in Leukemia and the Infectious Disease Society of America [2, 7])

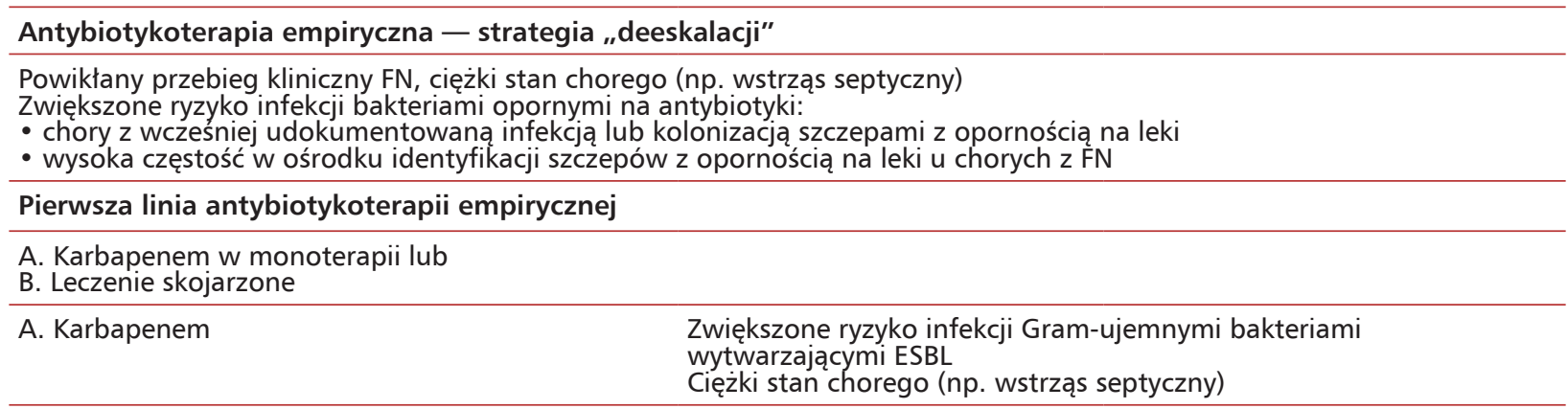

B. Leczenie skojarzone

Jeden z antybiotyków: piperacylina/tazobaktam, cefalosporyna (cefepim lub ceftazydym), tikarcylina/kwas klawulonowy, cefoperazon/sulbaktam lub karbapenem plus jeden z poniższych

Wankomycyna lub linezolid

Zwiększone ryzyko infekcji MRSA (wankomycyna) lub VRE (linezolid) Niestabilność hemodynamiczna lub inne objawy posocznicy, wstrząs septyczny, zapalenie płuc

Podejrzenie infekcji związanej z centralnym cewnikiem żylnym Zakażenie skóry lub tkanek miękkich

Kolistyna lub tygecyklina

Zwiększone ryzyko infekcji Gram-ujemnymi bakteriami wytwarzającymi karbapenemazę (w tym Kliebsiella pneumoniae wytwarzająca $\beta$-laktamazę typu KPC) Wstrząs septyczny, ciężki stan chorego

Aminoglikozyd

Zwiększone ryzyko infekcji pałeczkami niefermentującymi (Pseudomonas aeruginosa, Acinetobacter spp.)

Ciężki stan chorego (np. wstrząs septyczny)

\section{Weryfikacja postępowania terapeutycznego po 72-96 h leczenia*}

Pogorszenie stanu chorego

Należy powtórzyć badania mikrobiologiczne oraz obrazowe:

- rozważyć zastosowanie kolistyny lub innego antybiotyku aktywnego wobec bakterii Gram-ujemnych

- rozważyć zastosowanie leku aktywnego wobec opornych bakterii Gram-dodatnich

- rozważyć wskazania do leczenia przeciwgrzybiczego - po 4-7 dniach antybiotykoterapii rozpocząć empiryczne leczenie przeciwgrzybicze lub postępować zgodnie ze strategią leczenia wyprzedzającego

- rozważyć wskazania do leczenia przeciwwirusowego

- rozważyć inną przyczynę pogorszenia stanu chorego
Stan chorego ciężki wyjściowo, Stan chorego stabilny wyjściowo bez pogorszenia po 72-96 h i stabilny po 72-96 h leczenia leczenia

Należy kontynuować terapię

Chory bez gorączki

1. Jeżeli wyjściowo klinicznie zidentyfikowano ognisko infekcji, to należy:

- zmodyfikować antybiotykoterapię na podstawie danych klinicznych

- rozważyć odstapienie od podawania aminoglikozydu, fluorochinolonu lub kolistyny, jeśli stosowano leczenie skojarzone

2. Jeżeli wyjściowo rozpoznano FUO, to należy:

- zmienić karbapenem na jeden z antybiotyków o węższym spektrum działania zalecany w antybiotykoterapii empirycznej

- odstąpić od podawania aminoglikozydu, fluorochinolonu kolistyny lub antybiotyku aktywnego wobec bakterii Gram-dodatnich, jeśli stosowano leczenie skojarzone

- rozważyć zakończenie antybiotykoterapii po upływie $\geq 72$ h leczenia, jeśli chory nie goracczkuje przez $\geq 48 \mathrm{~h}$

Chory gorączkujący:

- zwykle brak wskazań do zmiany antybiotyków

- należy powtórzyć badania mikrobiologiczne oraz rozważyć ponowne badania obrazowe

*Jeżeli czynnik etiologiczny udokumentowano mikrobiologicznie, to dalsza antybiotykoterapia zgodna z wrażliwościa in vitro zidentyfikowanego mikroorganizmu lekami o węższym spektrum działania; zalecana konsultacja z mikrobiologiem klinicznym lub specjalistą ds. zakażeń; FN (febrile neutropenia) - gorączka neutropeniczna;
ESBL (extended-spectrum beta-lactamases) — $\beta$-laktamazy o rozszerzonym spektrum działania; MRSA (methicyllin-resistant Staphylococcus aureus) - gronkowiec złocisty oporny na metycylinę; VRE (vancomycin-resistant Enterococcus) - enterokoki oporne na wankomycynę; KPC (Kliebsiella pneumoniae carbapenemase) - karbapenemaza Klebsiella pneumoniae; FUO (fever of unkonwn origin) - gorączka nieznanego pochodzenia 
ze strategią leczenia wyprzedzającego (patrz dalej Zakażenia grzybicze).

U chorych, u których udokumentowano klinicznie ognisko zakażenia lub zidentyfikowano mikrobiologicznie czynnik etiologiczny leczenie powinno być zmodyfikowane stosownie do uzyskanych danych. Zaleca się, aby leczenie celowane kontynuowano do czasu ustąpienia objawów zakażenia i wzrostu liczby neutrofilów powyżej $0,5 \mathrm{G} / 1[1,2,8]$.

Antybiotykoterapia empiryczna u chorego, u którego nie udokumentowano źródła zakażenia w klasycznym ujęciu, może być zakończona, jeżeli gorączka oraz inne objawy infekcji ustąpiły i przez 48 godzin nie stwierdza się ich nawrotu, a liczba neutrofilów zwiększyła się powyżej 0,5 G/1. Europejskie zalecenia sformułowane $\mathrm{w}$ ostatnich latach pozwalają na zakończenie antybiotykoterapii empirycznej już po 72 godzinach niezależnie od liczby neutrofilów u chorych wyjściowo stabilnych hemodynamicznie, u których gorączka ustąpiła i przez 48 godzin nie stwierdza się jej nawrotu [7]. Chorzy powinni wówczas pozostać w szpitalu pod ścisłą obserwacją przez przynajmniej 48 godzin, by możliwe było natychmiastowe wdrożenia antybiotykoterapii w przypadku nawrotu gorączki. U tych chorych można rozważyć ponowne włącznie profilaktyki przeciwbakteryjnej do czasu ustąpienia neutropenii.

\section{Zakażenia grzybicze}

\section{Epidemiologia i czynniki ryzyka}

Zakażenia grzybicze, według stopnia penetracji tkanek, dzieli się na powierzchowne (grzybica skóry, włosów, paznokci lub błon śluzowych) oraz głębokie, inaczej układowe. Grzybica układowa może dotyczyć jednego lub większej liczby narządów i jest równiė nazywana inwazyjnym zakażeniem grzybiczym (IFI, invasive fungal infection) [9-11]. Do grzybów, które mogą wywoływać IFI, zalicza się:

- grzyby drożdżopodobne: Candida, Cryptococcus, Trichosporon, Blastoschizomycetes, Malassezia;

- grzyby pleśniowe: Aspergillus, Fusarium, Scedosporium, Mucorales (Rhizopus, Mucor, Rhizomucor, Absidia);

- grzyby dimorficzne (forma grzyba zmienia się zależnie od zasiedlanego otoczenia): Coccidioides, Histoplasma, Paracoccidioides, Blastomyces.

Historycznie najczęstszym identyfikowanym czynnikiem etiologicznym IFI u chorych $z$ upośledzoną odpornością były grzyby $z$ rodzaju Candida, przede wszystkim $z$ gatunku Candida albicans. Epi- demiologia zakażeń grzybiczych ulega jednak zmianom, głównie w wyniku stosowanego leczenia przeciwgrzybiczego. W ostatniej dekadzie obserwowano stopniowy wzrost częstości zachorowań wywołanych grzybami pleśniowymi, przede wszystkim $\mathrm{z}$ rodzaju Aspergillus spp., które stały się dominującym czynnikiem etiologicznym IFI w populacji chorych na nowotwory hematologiczne. Zwiększa się również częstość zakażeń wywołanych grzybami pleśniowymi z gromady Zygomycota (z rzędu Mucorales) oraz rodzajów Fusarium, Scedosporium i Acremonium, w przeszłości uważanych za niechorobotwórcze. Wśród zakażeń grzybami drożdżopodobnymi wzrasta częstość występowania szczepów tak zwanych non-albicans Candida (NAC): C.glabrata, C. krusei, C. parapsilosis i C. tropicalis [12].

Chorzy $z$ upośledzoną odpornością są stratyfikowani do trzech grup ryzyka wystąpienia IFI ze względu na częstość występowania grzybic układowych i śmiertelność w ich przebiegu (tab. 4) [13]. Do grupy najwyższego ryzyka należą chorzy na ostrą białaczkę szpikową (AML, acute myeloid leukemia) i zespoły mielodysplastyczne (MDS, myelodysplastic syndromes) z przedłużoną, ciężką neutropenią indukowaną intensywną chemioterapią $[1,2,13,14]$. W okresie po allo-HSCT szczególnie narażeni na IFI są chorzy $z$ opóźnioną regeneracją hematopoezy oraz leczeni z powodu GvHD. Do czynników ryzyka wystąpienia grzybicy układowej należy zaliczyć ciężką neutropenię trwającą 10 dni lub dłużej, kortykosteroidoterapię (w dawce równoważnej $\geq 0,3 \mathrm{mg} / \mathrm{kg} \mathrm{mc}$. prednizonu/d. stosowanej $\geq 3$ tygodnie), uszkodzenie błon śluzowych przewodu pokarmowego, przebyte wcześniej zakażenie grzybami pleśniowymi, a w odniesieniu do inwazyjnej kandydozy - dodatkowo obecność CVC [1, 2]; IFI są obarczone 30-70-procentową śmiertelnością.

\section{Obraz kliniczny i diagnostyka IFI}

Rozpoznanie IFI nie jest latwe, ponieważ objawy kliniczne zwykle są mało charakterystyczne, a przebieg u chorego $z$ upośledzoną odpornością - skąpoobjawowy. Najczęstszym i często jedynym objawem grzybicy układowej jest gorączka. $\mathrm{U}$ chorych $\mathrm{z}$ neutropenią podejrzenie inwazyjnej grzybicy powinno nasuwać utrzymywanie się lub nawrót gorączki mimo stosowania antybiotykoterapii empirycznej o szerokim spektrum działania przez 4 lub więcej dni [1, 2, 14]. Należy jednak pamiętać, że około 10\% IFI przebiega bez gorączki.

Zakażenia grzybami drożdżopodobnymi, które są składnikiem flory skóry, przewodu pokarmowego i dróg moczowo-płciowych, mają najczęściej 
Tabela 4. Stratyfikacja chorych z upośledzoną odpornością na grupy ryzyka według częstości występowania inwazyjnych zakażeń grzybiczych i śmiertelności w ich przebiegu (źródło [13])

Table 4. Stratification immunocompromised patients into risk groups according to the incidence of invasive fungal infections and mortality in their course (source [13])

\begin{tabular}{ll}
\hline Niskie ryzyko & Przeszczepienie autologicznych krwiotwórczych komórek macierzystych \\
& Chłoniak Hodgkina \\
& Nowotwory mieloproliferacyjne \\
Szpiczak plazmocytowy & Przewlekła choroba układu immunologicznego \\
& Toczeń układowy \\
\hline Pośrednie ryzyko & Ostra białaczka limfoblastyczna \\
& Przewlekła białaczka limfocytowa \\
& Przewlekła obturacyjna choroba płuc \\
& AlDS (acquired immune deficiency syndrome) \\
Zespoły mielodysplastyczne \\
\hline Ostra białaczka szpikowa \\
Przeszczepienie allogenicznych krwiotwórczych komórek macierzystych \\
Transplantacje serca, płuc i wątroby
\end{tabular}

charakter endogenny. Beżowo-białe naloty, ból i pieczenie $\mathrm{w}$ jamie ustnej towarzyszą kandydozie błony śluzowej jamy ustnej i gardła, która może się rozprzestrzeniać na przełyk (odynofagia) lub nagłośnię (stridor krtaniowy). W przebiegu kandydemii i rozsianej kandydozy z zajęciem wątroby, śledziony, nerek, wsierdzia czy opon mózgowo-rdzeniowych pojawia się gorączka. Do zakażenia grzybami z rodzaju Aspergillus najczęściej dochodzi drogą wziewną [9-11].

Inwazyjna aspergiloza płuc objawia się kaszlem u ponad $90 \%$ chorych, a ponadto dusznością i hipoksemią. Angioinwazyjny charakter grzybicy kropidlakowej płuc odpowiada za zmiany krwotoczne, zakrzepowe i martwicze tkanki płucnej, co klinicznie objawia się bólami w klatce piersiowej i krwiopluciem. Lokalizacja zmian grzybiczych w ośrodkowym układzie nerwowym (OUN) może prowadzić do udaru mózgu, krwotoku wewnątrzczaszkowego, zapalania opon mózgowo-rdzeniowych lub wytworzenia ropni. W zakażeniu zatok pojawia się ostry miejscowy ból. W przypadku zajęcia skóry obecne są charakterystyczne martwicze guzki i owrzodzenia. Zakażenie grzybami pleśniowymi z gromady Zygomycota najczęściej przebiega pod postacią ciężkiego zapalenia płuc, zatok obocznych nosa, tkanek oczodołu, mózgu lub skóry. W przebiegu fuzariozy obserwuje się rozsiane zmiany skórne i fungemię [9-11].

W przypadku podejrzenia grzybicy układowej należy niezwłocznie wykonać badania obrazowe klatki piersiowej, zatok przynosowych, jamy brzusznej i OUN w poszukiwaniu najczęściej spotykanych zmian (tab. 5) [15]. Ponadto należy rozważyć przeprowadzenie badań endoskopowych.

Podejrzenie IFI wymaga przeprowadzenia wnikliwych badań mikrobiologicznych. Klasyczne posiewy i hodowla materiału biologicznego w przypadku zakażeń grzybiczych cechują niska czułość i długi czas do uzyskania wyników. Wykorzystanie metod monitorowania biomarkerów serologicznych i molekularnych zakażenia grzybiczego u chorych, u których ryzyko wystąpienia IFI jest wysokie, umożliwia szybsze ustalenie rozpoznania i wdrożenie leczenia przeciwgrzybiczego.

Podstawą diagnostyki mikrobiologicznej zakażeń grzybiczych są klasyczne metody mikrobiologiczne, metody serologiczne oraz molekularne $[9,11,16,17]$. Klasyczne metody mikrobiologiczne:

- metody mikroskopowe - preparaty bezpośrednie lub barwione metodą Grama do oceny cytologicznej lub histopatologicznej:

- posiew i hodowla materiału biologicznego - charakteryzuje długi czas wzrostu (do kilku tygodni) i niska czułość, ale zaletą jest możliwość oceny lekowrażliwości;

- metody serologiczne - wykrywanie w surowicy swoistych przeciwciał lub częściej rozpuszczalnych antygenów grzybiczych metodą immunoenzymatyczną lub odczynem aglutynacji lateksowej:

- GM - składnik ściany grzybów rodzaju Aspergillus; możliwa reakcja krzyżowa z Histoplasma capsulatum: 
Tabela 5. Kryteria rozpoznawania prawdopodobnego inwazyjnego zakażenia grzybiczego (IFI) (wg The European Organisation for Research and Treatment of Cancer [15])

Table 5. Diagnostic criteria for probable invasive fungal infection (IFI) (acc. to The European Organization for Research and Treatment of Cancer [15])

\section{Czynniki usposabiające do wystąpienia IFI związane z chorym}

1. Ciężka neutropenia (<0,5 G/l przez > 10 dni) czasowo związana z pojawieniem się objawów IFI

2. Przeszczepienie allogenicznych krwiotwórczych komórek macierzystych

3. Przedłużona kortykosteroidoterapia (średnia dawka równoważna $\geq 0,3 \mathrm{mg} / \mathrm{kg} \mathrm{mc}$. prednizonu/d. stosowana przez $\geq 3$ tyg.)

4. Leczenie immunosupresyjne upośledzające czynność limfocytów T (cyklosporyna, inhibitory TNF $\alpha$, analogi puryn, przeciwciała monoklonalne, takie jak alemtuzumab) w okresie ostatnich 3 miesięcy

5. Wrodzone ciężkie zaburzenia odporności (takie jak przewlekła choroba ziarniniakowa czy ciężki złożony niedobór odporności)

Kryteria kliniczne zakażenia (pozostające w związku czasowym z obecnym epizodem infekcji oraz zgodne z wynikami badań mykologicznych)

1. Inwazyjna grzybica dolnych dróg oddechowych

Obecność 1 z poniższych nieprawidłowych obrazów w tomografii komputerowej:

- dobrze ograniczone zagęszczenie z objawem "halo" lub bez niego

- objaw powietrznego rąbka w kształcie półksiężyca

- jama

Konieczna jednoczesna diagnostyka w celu wykluczenia innych niż grzyby czynników etiologicznych

2. Zapalenie tchawicy i oskrzeli - owrzodzenia, guzki, błony rzekome, blaszki lub strupy w badaniu bronchoskopowym

3. Zapalenie zatok przynosowych lub błony śluzowej jamy nosowej

Objawy zapalenia zatok w badaniach obrazowych oraz obecność $\geq 1$ z poniższych objawów:

- ostry, zlokalizowany ból (w tym promieniujący w kierunku oka)

- owrzodzenie błony śluzowej nosa pokryte czarnymi strupami

- rozszerzanie się zakażenia przez bariery kostne (w tym w kierunku oczodołów)

4. Zakażenie ośrodkowego układu nerwowego

Obecność jednego z poniższych objawów:

- zmiany ogniskowe w badaniach obrazowych

- pogrubienie opon mózgowych w obrazowaniu metodą rezonansu magnetycznego lub tomografii komputerowej

5. Rozsiana kandydoza

Obecność $\geq 1$ z poniższych zaburzeń u chorych z epizodem kandydemii w czasie ostatnich 2 tygodni:

- małe ropnie o obrazie „wolego oka” (tj. hiperechogenicznego centrum otoczone przez hipoechogeniczną otoczkę) w wątrobie lub śledzionie

- postępujący wysięk siatkówkowy w badaniu oftalmoskopowym

Kryteria mykologiczne

Metody bezpośrednie (badanie cytologiczne, preparaty bezpośrednie, hodowla) — wykrycie w ślinie, popłuczynach pęcherzykowo-oskrzelikowych, wymazie szczoteczkowym oskrzeli lub aspiracie z zatok 1 z poniższych:

- fragmentów grzyba charakterystycznych dla pleśni w badaniu mikroskopowym

- grzybów pleśniowych w hodowli materiału biologicznego (tj. Aspergillus, Fusarium, Zygomycota, Scedosporium) Metody pośrednie:

- aspergiloza - wykrycie galaktomannanu w surowicy/osoczu, popłuczynach pęcherzykowo-oskrzelikowych lub płynie mózgowo-rdzeniowym

- inwazyjne zakażenie grzybicze inne niż kryptokokoza lub zygomykoza — wykrycie $\beta$-D-glukanu w surowicy

TNF $\alpha$ (tumor necrosis factor $\alpha$ ) - czynnik martwicy nowotworów $\alpha$

a) GM można oznaczać w surowicy/osoczu, popłuczynach oskrzelowo-pęcherzykowych (BAL, bronchoalveolar lavage), płynie mózgowo-rdzeniowym $\mathrm{i}$ innych płynach ustrojowych; b) stężenie GM wykryte w teście jest wyrażane jako tak zwany wskaźnik; pojedynczy wynik większy lub równy 0,7 lub dwa wyniki większe lub równe 0,5 w surowicy/ 
/osoczu uznaje się za dodatnie i wymagają rozszerzenia diagnostyki (ocena kliniczna oraz mikrobiologiczna, CT wysokiej rozdzielczości płuc, badania endoskopowe); dla BAL i płynu mózgowo-rdzeniowego za wynik dodatni przyjmuje się wartość większą lub równą 1 ( $\geq 0,5 \mathrm{wg}$ Food and Drug Administration i niektórych grup ekspertów);

c) czułość i specyficzność badania GM we krwi chorych na nowotwory hematologiczne poddawanych intensywnej chemioterapii wynosi odpowiednio około $60 \%$ i $95 \%$, a po HSCT - około $65 \%$; ocena GM w BAL ma większą czułość (80\%) niż posiew tego materiału (50\%);

d) monitorowanie GM dwa razy w tygodniu zaleca się u chorych $z$ neutropenią obciążonych wysokim ryzykiem rozwoju inwazyjnej aspergilozy (tj. u chorych na AML i MDS poddanych intensywnej chemioterapii oraz u chorych we wczesnym okresie po allo-HSCT);

e) wynik fałszywie dodatni może być spowodowany leczeniem antybiotykiem $\beta$-laktamowym skojarzonym $z$ inhibitorem $\beta$-laktamazy (np. piperacylina/tazobaktam), a wynik fałszywie ujemny - stosowaniem leków aktywnych wobec pleśni (np. worikonazol, pozakonazol),

- $\beta$-(1-3)-D-glukan — składnik ściany drożdżaków (głównie Candida), grzybów pleśniowych $z$ rodzaju Aspergillus i Fusarium oraz wielu innych, $z$ wyjątkiem $Z y g o m y$ cota i Cryptococcus:

a) antygen oznacza się w surowicy, a wynik jest wyrażany jako stężenie antygenu,

b) dwa dodatnie wyniki badania cechują 100-procentowa czułość i 45-65-procentowa specyficzność,

c) wynik fałszywie dodatni może być spowodowany przetaczaniem preparatów krwiopochodnych, hemodializą, hemofiltracją, stosowaniem antybiotyków $\beta$-laktamowych, przetoczeniami immunoglobulin, hemolizą, bakteriemią czy mętnością surowicy,

- antygen Cryptococcus - składnik otoczki polisacharydowej Cryptococcus oznacza się w płynie mózgowo-rdzeniowym i w surowicy u chorych $z$ podejrzeniem kryptokokowego zapalenia opon mózgowo-rdzeniowych lub rozsianego zakażenia;

- metody molekularne - wykrywanie materiału genetycznego grzybów metodą reakcji łańcu- chowej polimerazy (PCR, polymerase chain reaction); zależnie od zastosowanych starterów można wykrywać materiał genetyczny obecny we wszystkich grzybach (tzw. panfungal test) lub specyficzny dla rodzaju czy gatunku grzyba:

- testy molekularne wykonywane we krwi lub BAL u chorych $z$ neutropenią cechują wysoka czułość (75-80\%) i swoistość (75-90\%) w wykrywaniu inwazyjnej aspergilozy;

- obecnie zastosowanie w codziennej praktyce nie może być rekomendowane ze względu na brak standaryzacji i walidacji testów.

Na podstawie identyfikacji czynników usposabiających do zakażenia grzybiczego, objawów klinicznych oraz wyników badań mykologicznych rozpoznanie IFI u chorych $z$ upośledzoną odpornością według powszechnie stosowanej klasyfikacji EORTC (European Organisation for Research and Treatment of Cancer) uznaje się za:

- potwierdzone (proven) w przypadku dodatnich wyników klasycznych badań mikrobiologicznych $z$ materiału pobranego $z$ miejsc zwykle jałowych ( $z$ wyłączeniem BAL, moczu i aspiratu pobranego $z$ zatok obocznych nosa) lub z krwi, niezależnie od spełnienia kryteriów klinicznych i obecności czynników usposabiających zależnych od chorego;

- prawdopodobne (probable), jeżeli u chorego z czynnikami usposabiającymi do wystąpienia inwazyjnej grzybicy stwierdza się dodatnie wyniki klasycznych badań mikrobiologicznych $z$ okolic ciała mających kontakt ze środowiskiem zewnętrznym (plwocina, BAL, aspirat $z$ zatok obocznych nosa) lub dodatni wynik testów pośrednich (badań serologicznych) przy spełnieniu kryteriów klinicznych (objawy podmiotowe/przedmiotowe i radiologiczne);

- możliwe (possible), jeżeli u chorego zidentyfikowano czynniki usposabiające do IFI i są spełnione kryteria kliniczne, ale wyniki badań mykologicznych pozostają ujemne.

Kryteria EORTC, które służą rozpoznaniu prawdopodobnego lub możliwego IFI u chorych $z$ upośledzoną odpornością, przedstawiono w tabeli 5 [15].

\section{Leczenie zakażeń grzybiczych}

W zależności od przyjętej strategii diagnostyczno-terapeutycznej postępowanie przeciwgrzybicze można podzielić na profilaktykę (pierwotną i wtórną), leczenie empiryczne, wyprzedzające oraz celowane. 
Profilaktyka pierwotna i wtórna

Profilaktyka pierwotna dotyczy chorych, u których wcześniej nie rozpoznano zakażenia grzybiczego. Jest zalecana u chorych obciążonych wysokim ryzykiem wystąpienia IFI, określanym zwykle jako przekraczające $10 \%(1,2,14,18)$. Do tej grupy zalicza się chorych:

- na AML i MDS poddanych intensywnej chemioterapii;

- we wczesnym okresie po allo-HSCT lub leczonych z powodu GvHD;

- na ostre białaczki limfoblastyczne w okresie CIN;

- poddanych auto-HSCT $z$ wysokim ryzykiem zapalenia błon śluzowych.

Zastosowanie pierwotnej profilaktyki u wymienionych wyżej chorych prowadzi do zmniejszenia częstości występowania IFI, zmniejszenia śmiertelności związanej $z$ inwazyjnymi grzybicami oraz poprawy przeżycia. Niekorzystnym następstwem pierwotnej profilaktyki jest możliwość selekcji opornych szczepów grzybów (C. glabrata i C. krusei $\mathrm{w}$ wyniku stosowania azoli). Nie należy jej zatem stosować u chorych, u których ryzyko IFI nie jest wysokie.

Zgodnie $z$ zaleceniami międzynarodowych towarzystw naukowych i grup ekspertów w pierwotnej profilaktyce u chorych po allo-HSCT bez objawów GvHD, po auto-HSCT $z$ wysokim ryzykiem zapalenia błon śluzowych oraz u chorych na ostre białaczki limfoblastyczne w okresie CIN należy zastosować flukonazol $[1,2,14,18]$. U chorych po allo-HSCT $z$ objawami GvHD oraz u chorych na AML i MDS z CIN natomiast zaleca się pozakonazol $[1,2,14,18]$. Zastosowanie tych leków w wymienionych wskazaniach jest oparte na dowodach najwyższej jakości. Do innych wymienianych leków, które można rozważyć w pierwotnej profilaktyce, należą $[1,2,14,18]$ :

- worikonazol - zalecany przez większość grup eksperckich u chorych w okresie neutropenii po allo-HSCT lub $z$ objawami GvHD oraz przez niektóre $z$ nich u chorych na AML w okresie CIN ze szczególnie wysokim ryzykiem IFI;

- itrakonazol (doustnie w postaci zawiesiny; podany w formie tabletek wchłania się nierównomiernie) - rekomendowany przez niektóre grupy ekspertów u chorych na ostre białaczki z CIN lub po allo-HSCT;

- liposomalna amfoterycyna B w inhalacjach (12,5 mg przez 2 kolejne dni tygodnia) lub dożylnie (1 mg/kg mc. co 2. dzień lub 2,5 mg/ /kg mc. 2 razy/tydzień) w skojarzeniu $z$ flukonazolem - rekomendowana przez niektóre grupy ekspertów w okresie neutropenii we wczesnej fazie po allo-HSCT lub u chorych na AML w okresie CIN;

- mykafungina, kaspofungina - rekomendowane przez niektóre grupy ekspertów u chorych po allo-HSCT $z$ objawami GvHD lub u chorych na AML $z$ długotrwałą neutropenią.

Przyjmuje się, że profilaktyka pierwotna u chorych po allo-HSCT powinna być stosowana przez pierwsze 75-100 dni po transplantacji lub do czasu zakończenia leczenia immunosupresyjnego u chorych $z$ GvHD. U chorych na AML/MDS czas trwania profilaktyki ogranicza się do okresu ciężkiej neutropenii.

Profilaktyka wtórna oznacza działania zapobiegające nawrotowi wcześniej rozpoznanego IFI lub wystąpieniu kolejnego IFI u chorego, u którego ponownie pojawiły się czynniki do niego usposabiające. Wybór leku stosowanego $\mathrm{w}$ profilaktyce wtórnej powinien być podyktowany rodzajem zidentyfikowanego patogenu oraz odpowiedzią na leczenie podczas wcześniejszego epizodu IFI.

\section{Leczenie empiryczne}

Empiryczne leczenie przeciwgrzybicze jest elementem algorytmu postępowania u chorych z FN indukowaną chemioterapią. Polega na zastosowaniu leku przeciwgrzybiczego u chorych bez potwierdzonych klinicznych i mikrobiologicznych cech IFI, u których FN nawraca lub utrzymuje się mimo stosowania antybiotykoterapii o szerokim spektrum działania przez 4-7 dni [19, 20]. Z jednej strony wczesne wdrożenie terapii zmniejsza częstość grzybic narządowych i śmiertelność $z$ ich powodu. $Z$ drugiej strony przetrwała lub nawrotowa FN to słaby czynnik predykcyjny IFI, a zatem część chorych jest narażona na niepotrzebne leczenie i toksyczność z nim związaną. Dlatego w indywidualnych przypadkach uzasadnione jest późniejsze rozpoczęcie, a nawet zaniechanie empirycznego leczenia przeciwgrzybiczego. Leki przeciwgrzybicze zalecane w terapii empirycznej przez międzynarodowe towarzystwa naukowe i grupy eksperckie przedstawiono w tabeli $6[1,14,18,21]$.

W doborze rodzaju leku i jego dawkowania powinno się również uwzględnić rodzaj stosowanej profilaktyki przeciwgrzybiczej. Jeżeli chory otrzymywał antybiotyk polienowy, to w profilaktyce należy zwiększyć jego dawkę albo zmienić na worikonazol lub echinokandynę. Skuteczność itrakonazolu i worikonazolu natomiast może być mniejsza u chorych otrzymujących w profilaktyce lek z grupy azoli. 
Tabela 6. Leki przeciwgrzybicze zalecane w terapii empirycznej (na podstawie wytycznych European Conference on Infections in Leukemia oraz National Comprehensive Cancer Network [1, 14])

Table 6. Antifungal drugs recommended for empiric therapy (based on the guidelines of the European Conference on Infections in Leukemia and the National Comprehensive Cancer Network [1, 14])

\begin{tabular}{|c|c|c|}
\hline Lek & Dawka dobowa & Uwagi \\
\hline Liposomalna amfoterycyna B & Dożylnie 3 mg/kg mc. & \multirow{2}{*}{$\begin{array}{l}\text { Najwyższa kategoria rekomendacji u chorych } \\
\text { na ostre białaczki i po HSCT }\end{array}$} \\
\hline Kaspofungina & Dożylnie 50 mg & \\
\hline $\begin{array}{l}\text { Amfoterycyna B w postaci } \\
\text { kompleksu lipidowego }\end{array}$ & Dożylnie 4-5 mg/kg mc. & \multirow{4}{*}{$\begin{array}{l}\text { Wysoka kategoria rekomendacji u chorych } \\
\text { na ostre białaczki i po HSCT }\end{array}$} \\
\hline Itrakonazol & Dożylnie $200-400 \mathrm{mg}$ & \\
\hline Worikonazol & Dożylnie $2 \times 3 \mathrm{mg} / \mathrm{kg} \mathrm{mc}$. & \\
\hline Mykafungina & Dożylnie 100 mg & \\
\hline Konwencjonalna amfoterycyna B & Dożylnie $0,5-1 \mathrm{mg} / \mathrm{kg} \mathrm{mc}$. & $\begin{array}{l}\text { Wysoka kategoria rekomendacji u chorych na ostre } \\
\text { białaczki i po HSCT, u których nie stwierdza się dodat- } \\
\text { kowych czynników ryzyka wystąpienia objawów nefro- } \\
\text { toksycznych (np. jednoczesne stosowanie innych leków } \\
\text { nefrotoksycznych) }\end{array}$ \\
\hline
\end{tabular}

HSCT (hematopoietic stem cell transplantation) - przeszczepienie krwiotwórczych komórek macierzystych

\section{Leczenie wyprzedzające}

Leczenie wyprzedzające oznacza rozpoczęcie leczenia przeciwgrzybiczego $u$ chorych $z$ neutropenia na podstawie kompleksowej oceny obecności czynników ryzyka, objawów klinicznych i radiologicznych IFI oraz analizy wyników seryjnie wykonywanych oznaczeń wczesnych biomarkerów IFI (tj. GM, $\beta$ -D-glukanu lub badania molekularne) $[14,19,20]$. Celem tej strategii jest ograniczenie grupy chorych z FN, u których stosuje się leki przeciwgrzybicze. Leczenie wyprzedzające nie stało się jednak dotychczas standardem postępowania klinicznego ze względu na brak jednoznacznych i powszechnie przyjętych kryteriów definiujących wskazania do jego rozpoczęcia, jak również wystarczającej liczby danych pochodzących $z$ randomizowanych badań klinicznych.

\section{Leczenie celowane}

Leczenie celowane oznacza terapię prawdopodobnego lub potwierdzonego IFI. Dobór rodzaju leku i jego dawkowanie są dostosowane do rodzaju patogenu (tab. 7, 8) [1, 14, 21, 22].

Leczenie farmakologiczne IFI powinno być kontynuowane do czasu ustąpienia neutropenii, a następnie do ustąpienia zmian grzybiczych, maksymalnie do 12 tygodni. Czas trwania terapii inwazyjnej kandydozy powinien być nie krótszy niż 14 dni od uzyskania ujemnych posiewów krwi, ustąpienia objawów klinicznych i radiologicznych zakażenia oraz wzrostu liczby granulocytów powyżej 0,5 G/1. Leczenie kandydozy OUN nie powinno trwać krócej niż 4 tygodnie.

W terapii IFI istotną rolę odgrywa również leczenie wspomagające. $\mathrm{W}$ przebiegu neutropenii należy rozważyć zastosowanie G-CSF, a u chorych leczonych $z$ powodu GvHD — zmniejszenie dawek leków immunosupresyjnych, w szczególności kortykosteroidów. U chorych $z$ kandydemią konieczne jest usunięcie CVC. W przypadku izolowanej narządowej aspergilozy należy rozważyć chirurgiczne usunięcie zmiany. Leczenie chirurgiczne jest kluczowe w leczeniu inwazyjnych zakażeń spowodowanych grzybami z gromady Zygomycota (mukormykoz), które są obarczone bardzo wysoką śmiertelnością. W ich zwalczaniu można rozważyć tlenoterapię hiperbaryczną, choć jakość dowodów na skuteczność takiego postępowania nie jest wysoka. W leczeniu fuzariozy również należy rozważyć chirurgiczne usunięcie zainfekowanych tkanek oraz usunąć CVC. Śmiertelność w przebiegu tej rzadkiej grzybicy również jest bardzo wysoka.

\section{Zakażenia wirusowe}

Wirusy stanowią częstą przyczynę powikłań infekcyjnych u chorych po HSCT, jak również leczonych analogami puryn, przeciwciałami monoklonalnymi oraz inhibitorami proteasomu z powodu nowotworów układu chłonnego. Najczęściej są rozpoznawane zakażenia wywołane herpeswirusami: wirusem opryszczki pospolitej (HSV-1 i HSV-2; herpes simplex virus), wirusem ospy wietrznej i półpaśca (VZV, Varicella zoster virus), CMV, wirusami rumienia nagłego (inaczej HHV-6 i HHV-7, human herpesvirus-6 i -7) oraz wirusem Epstein-Barr (EBV, Epstein-Barr virus) [23]. Wspólną cechą herpeswirusów jest zdolność do wywoływania zakażeń utajonych (latentnych), 
Tabela 7. Leki przeciwgrzybicze zalecane w terapii celowanej (na podstawie wytycznych European Conference on Infections in Leukemia, National Comprehensive Cancer Network oraz German Society of Hematology and Oncology [1, 14, 21, 22])

Table 7. Antifungal drugs recommended for targeted therapy (based on the guidelines of the European Conference on Infections in Leukemia, the National Comprehensive Cancer Network and the German Society of Hematology and Oncology [1, $14,21,22])$

\begin{tabular}{ll}
\hline Inwazyjna kandydoza & Uwagi \\
\hline Echinokandyny (mykafungina, kaspofungina) & Zalecane u chorych z neutropenią, w ciężkim stanie \\
& Preferowane w zakażeniach wywołanych przez C. glabrata \\
Liposomalna amfoterycyna B & Zmienna wrażliwość C. parapsilosis (rozważyć leki z innej grupy) \\
Worikonazol & Zalecana u chorych z neutropenią, w ciężkim stanie \\
& Preferowana w kandydozie OUN \\
Flukonazol & Zmienna wrażliwość C. glabrata \\
& Preferowany w kandydozie OUN \\
& Niezalecany u chorych leczonych wcześniej azolami, \\
& u chorych z neutropenią lub w ciężkim stanie \\
& Zalecany w zakażeniach wywołanych przez C. parapsilosis \\
& Zmienna wrażliwość C. glabrata, oporność C. krusei \\
\hline
\end{tabular}

Inwazyjna aspergiloza - leczenie I linii

Worikonazol Najwyższe kategoria rekomendacji i jakość dowodów

Lek z wyboru w aspergilozie OUN

Rozważyć lek z innej grupy w przypadku inwazyjnego zakażenia grzybiczego, które rozwinęło się $\mathrm{w}$ trakcie profilaktyki azolem aktywnym wobec pleśni

Liposomalna amfoterycyna B

Wysoka kategoria rekomendacji, najwyższa jakość dowodów

Amfoterycyna B w postaci kompleksu lipidowego

Wysokie kategoria rekomendacji i jakość dowodów

Kaspofungina

Pośrednie kategoria rekomendacji i jakość dowodów

Inwazyjna aspergiloza - leczenie II linii

Worikonazol

Stosowany w leczeniu II linii, jeżeli w I linii podawano inny lek

Kaspofungina

Wysokie kategoria rekomendacji i jakość dowodów

Liposomalna amfoterycyna B

Wysokie kategoria rekomendacji i jakość dowodów

Amfoterycyna B w postaci kompleksu lipidowego

Wysokie kategoria rekomendacji i jakość dowodów

Pozakonazol*

Wysokie kategoria rekomendacji i jakość dowodów

Należy podawać z posiłkiem lub płynnym suplementem diety;

jeżeli przyjmowanie posiłków przez chorego nie jest możliwe,

to rozważyć zastosowanie innego leku

Inwazyjna aspergiloza - leczenie ratunkowe

Kaspofungina w skojarzeniu z worikonazolem Pośrednie kategoria rekomendacji i jakość dowodów

Mukormykoza - leczenie I linii

Liposomalna amfoterycyna B

Najwyższa kategoria rekomendacji

Preferowana w grzybicy OUN i u chorych z upośledzeniem funkcji nerek

Amfoterycyna B w postaci kompleksu lipidowego

Mukormykoza - leczenie ratunkowe

Pozakonazol Najwyższa kategoria rekomendacji

Lipidowa postać amfoterycyny B w skojarzeniu

kaspofunginą

Lipidowa postać amfoterycyny B w skojarzeniu

pozakonazolem

Fuzarioza i zakażenie wywołane Scedosporium

Worikonazol

Liposomalna amfoterycyna B

Amfoterycyna B w postaci kompleksu lipidowego

Pozakonazol

*W 2014 roku dożylną postać pozakonazolu zatwierdzity European Medicines Agency w Europie i Food and Drug Administration w Stanach Zjednoczonych; od 2015 roku postać dożylna jest dostępna również w Polsce; OUN — ośrodkowy układ nerwowy 
Tabela 8. Dawkowanie leków przeciwgrzybiczych w terapii celowanej (źródła [1, 12, 21, 22])

Table 8. The dosage of antifungal agents in targeted therapy (sources [1, 12, 21, 22])

\begin{tabular}{lll}
\hline Lek & Dawka dobowa & Uwagi \\
\hline Liposomalna amfoterycyna B & Dożylnie $3 \mathrm{mg} / \mathrm{kg} \mathrm{mc}$. & W leczeniu aspergilozy ośrodkowego \\
& & układu nerwowego 3-5 mg/kg mc. \\
& & W leczeniu mukormykozy $\geq 5 \mathrm{mg} / \mathrm{kg} \mathrm{mc.}$
\end{tabular}

Amfoterycyna B w postaci kompleksu lipidowego

Worikonazol

Pozakonazol*

Mykafungina

Kaspofungina
Dożylnie $5 \mathrm{mg} / \mathrm{kg} \mathrm{mc}$.

Dożylnie pierwszy dzień $2 \times 6 \mathrm{mg} / \mathrm{kg} \mathrm{mc}$., Sugeruje się przydatność oznaczania kolejne dni $2 \times 4 \mathrm{mg} / \mathrm{kg} \mathrm{mc}$. doustnie $2 \times 200 \mathrm{mg}$

Doustnie $2 \times 400 \mathrm{mg}$ razem z posiłkami stęzenia leku w osoczu w celu uzyskania docelowego zakresu stężenia 1,0-5,0 mg/l

Sugeruje się przydatność oznaczania stężenia leku w osoczu w celu uzyskania docelowego stężenia $\geq 0,75 \mathrm{mg} / \mathrm{l}$

*W 2014 roku dożylną postać pozakonazolu zatwierdziły European Medicines Agency w Europie i Food and Drug Administration w Stanach Zjednoczonych; od 2015 roku postać dożylna jest dostępna również w Polsce; dawkowanie we wlewie dożylnym: pierwszy dzień $2 \times 300 \mathrm{mg}$, kolejne dni $1 \times 300 \mathrm{mg}$

które mogą następnie ulegać reaktywacji u chorych Z upośledzoną odpornością.

Zakażenia HSV i VZV u chorych z zaburzeniami odporności, poza typowymi objawami (zapalenia błon śluzowych i pęcherzykowate wykwity skórne), mogą powodować rozsiane zmiany skórne i zajmować narządy wewnętrzne, tj. wywoływać objawy brzuszne, ciężkie zapalenia płuc, mózgu lub wątroby.

Zakażenie CMV najczęściej jest rozpoznawane u chorych po allo-HSCT. Może przebiegać pod postacią pierwotnej lub nawrotowej infekcji (reaktywacji zakażenia) oraz choroby CMV. Infekcję CMV rozpoznaje się na podstawie wykrycia antygenu pp65 w leukocytach (tzw. antygenemia CMV) lub kwasu nukleinowego wirusa (DNA, rzadziej mRNA) w krwi lub osoczu chorego, u którego nie stwierdza się objawów klinicznych związanych $z$ infekcją $[23,24]$. W praktyce najczęściej wykorzystuje się wykrywanie CMV DNA metodą PCR. Przyjmuje się, że do rozpoznania infekcji CMV upoważnia jeden dodatni wynik badania na obecność antygenu pp65 lub dwa dodatnie wyniki badania CMV DNA metodą PCR. Pierwotną infekcję rozpoznaje się u chorego, u którego metodami serologicznymi nie stwierdza się przeciwciał anty-CMV, natomiast o nawrotowym charakterze infekcji świadczy obecność przeciwciał anty-CMV klasy IgG. Jeżeli $\mathrm{u}$ chorego $\mathrm{z}$ infekcją CMV występuje gorączka (z objawami zahamowania czynności szpiku lub bez nich) rozpoznaje się objawową infekcję CMV. Chorobę CMV natomiast rozpoznaje się u chorych z objawami narządowymi zakażenia, po potwierdzeniu odpowiednimi metodami obecności wirusa $\mathrm{w}$ materiale pobranym $\mathrm{z}$ zajętego narządu (hodowla tkankowa, szybka hodowla probówkowa, badania histopatologiczne, immunohistochemiczne).

Infekcja CMV to częste powikłanie po allo-HSCT [24]. Jest rozpoznawana u około 30\% seronegatywnych biorców poddanych allo-HSCT od seropozytywnych dawców. U biorców seropozytywnych, u których nie stosuje się profilaktyki przeciwwirusowej, odsetek infekcji może sięgać $80 \%$. Ryzyko infekcji jest wyższe u chorych z GvHD, leczonych dużymi dawkami kortykosteroidów oraz po transplantacji od dawcy alternatywnego. Reaktywacja CMV jest również rozpoznawana u ponad $10 \%$ chorych na nowotwory układu chłonnego niepoddanych HSCT, najczęściej u chorych na przewlekłą białaczkę limfocytową, chłoniaki nie-Hodgkina i szpiczaka plazmocytowego leczonych analogami puryn, alemtuzumabem lub inhibitorami proteasomu [1, 23]. Rozpoznanie infekcji CMV umożliwia wdrożenie terapii wyprzedzającej, której celem jest zahamowanie replikacji wirusa przed pojawieniem się objawów choroby CMV. U chorych po allo-HSCT zaleca się regularne oznaczanie antygenu pp65 lub CMV DNA (mRNA) we krwi przynajmniej raz w tygodniu przez 3-6 miesięcy po transplantacji. Dłuższe monitorowanie zaleca się u chorych z GvHD, po allo-HSCT od dawcy niespokrewnionego lub niezgodnego w układzie ludzkich antygenów leukocytarnych (HLA, human lymphocyte antigen). U chorych na przewlekłą 
białaczkę limfocytową leczonych alemtuzumabem badania te powinny być wykonywane $\mathrm{w}$ okresie podawania leku, a następnie przez 2 miesiące po zakończeniu immunoterapii. Regularne wykonywanie badań można rozważyć również u chorych po auto-HSCT leczonych wcześniej analogami puryn lub poddanych napromienianiu całego ciała [1, 23, 24].

Choroba CMV przebiega najczęściej pod postacią śródmiąższowego zapalenia płuc, zapalenia błony śluzowej przewodu pokarmowego, rzadziej wątroby, siatkówki lub mózgu. Śródmiąższowe zapalenie płuc po HSCT jest bardzo poważnym powikłaniem związanym $z$ ponad 50 -procentową śmiertelnością. Objawia się zwykle gorączką, suchym kaszlem, dusznością i hipoksją. W obrazie radiologicznym pluc stwierdza się nacieki o charakterze śródmiąższowym. Rozpoznanie powinno być potwierdzone wykryciem CMV w materiale uzyskanym drogą biopsji pluca lub BAL. Do zalecanych technik wykrywania CMV należą metoda hodowli tkankowej, szybkiej hodowli probówkowej i badanie histopatologiczne. Wykrycie CMV DNA w BAL nie wystarcza, by potwierdzić chorobę CMV (niskie dodatnia wartość predykcyjna i specyficzność). Badanie to może natomiast służyć wykluczeniu zakażenia CMV jako przyczyny zapalenia płuc (wysokie negatywna wartość predykcyjna i czułość). Rozpoznanie choroby CMV pod postacią zapalenia błony śluzowej przewodu pokarmowego nie jest łatwe. Objawy kliniczne nie są specyficzne (dysfagia, nudności wymioty, bóle brzucha, biegunki). W badaniach endoskopowych stwierdza się owrzodzenia, których makroskopowo nie można zróżnicować ze zmianami w przebiegu GvHD lub zakażenia adenowirusem. Potwierdzenie zakażenia CMV wymaga wykonania biopsji zajętej tkanki i wykrycia wirusa metodą hodowli tkankowej lub w badaniu histopatologicznym. W przebiegu zakażenia CMV u chorych $z$ upośledzoną odpornością może dojść do zajęcia niemal każdego narządu [1, 23, 24].

Zakażenie HHV-6 rozpoznaje się u chorych po allo-HSCT $z$ opóźnioną rekonstytucją krwiotworzenia oraz zapaleniem mózgu. Objawy braku przyjęcia przeszczepu i wykrycie DNA wirusa we krwi upoważnia do rozpoznania choroby HHV-6 po wykluczeniu innych przyczyn opóźnionej rekonstytucji hematopoezy. Choroba HHV-6 pod postacią zapalenia mózgu jest opisywana głównie u chorych po transplantacji komórek krwiotwórczych od dawcy niespokrewnionego lub niezgodnego w układzie HLA. Objawia się zaburzeniami świadomości, splątaniem, zaburzeniami pamięci krótkoterminowej, drgawkami. W obrazowaniu metodą rezonansu magnetycznego można wykryć wieloogniskowe zmiany w istocie szarej, zwykle obejmujące płaty skroniowe. Podstawą rozpoznania jest wykrycie w płynie mózgowo-rdzeniowym DNA wirusa. Opisywane są również przypadki zapalenia mózgu u chorych po HSCT wywołane HHV-7 [23].

Zakażenia EBV u chorych po HSCT jest odpowiedzialne za rozwój potransplantacyjnej choroby limfoproliferacyjnej [25], której omówienie przekracza ramy niniejszego artykułu.

Zasady profilaktyki i leczenia infekcji herpeswirusami zgodne $z$ zaleceniami międzynarodowych grup ekspertów przedstawiono w tabeli 9 [1,23].

Druga grupa zakażeń wirusowych rozpoznawanych u chorych po HSCT, rzadziej u chorych na białaczki i z innymi zaburzeniami odporności, to infekcje dróg oddechowych spowodowane najczęściej przez syncytialny wirus oddechowy (RSV, respiratory syncytial virus), wirusy grypy i paragrypy, koronawirusy, rynowirusy, ludzki adenowirus (AdV, adenovirus) lub metapneumowirus (MPV, metapneumovirus) [26]. Do zakażeń tych dochodzi w wyniku ekspozycji na wirusy, zwykle w okresie epidemii lub endemii. Infekcje wirusowe układu oddechowego mogą mieć zróżnicowany przebieg — od samoograniczającej się infekcji górnych dróg oddechowych (kaszel, ból gardła, duszność, nieżyt nosa), do ciężkich infekcji dolnych dróg oddechowych. Grypę należy podejrzewać w okresie jej sezonowego występowania u chorych na tak zwaną chorobą grypopodobną lub ostrą infekcję dróg oddechowych i uznać za prawdopodobną w przypadku wykrycia powiązania epidemiologicznego [27]. Zakażenie AdV, poza zapaleniem dróg oddechowych, może wywoływać również zapalenie jelit, wątroby, dróg moczowych i nerek, a w rzadkich przypadkach — mózgu, mięśnia sercowego i pancytopenię. Najczęściej występuje 2-3 miesiące po HSCT. Podstawą diagnostyki laboratoryjnej jest wykazanie obecności wirusa, jego antygenów lub kwasu nukleinowego $\mathrm{w}$ materiale klinicznym pobranym od chorego $z$ narządu objętego chorobą. Do badania pobiera się wymaz $z$ nosa lub gardła, aspirat $z$ nosogardła czy BAL. W celu potwierdzenia grypy zaleca się badanie molekularne metodą PCR materiału uzyskanego $z$ obustronnego wymazu $z$ nosogardła. W celu udokumentowania zakażenia AdV we krwi, stolcu lub moczu chorego oznacza się DNA wirusa metodą PCR. W przypadku występowania objawów ze strony OUN poszukuje się materiału genetycznego wirusa w płynie mózgowo-rdzeniowym. Zasady profilaktyki i leczenia zakażeń wywoływanych przez tę grupę wirusów przedstawiono w tabeli 10 [1, 26, 27].

W ostatnich latach zaobserwowano częsty i narastający problem reaktywacji infekcji wirusem 
Tabela 9. Zasady leczenia zakażeń herpeswirusami (na podstawie wytycznych European Conference on Infections in Leukemia oraz National Comprehensive Cancer Network [1, 23])

Table 9. Principles of the treatment of herpes virus infections (based on the guidelines of the European Conference on Infections in Leukemia and the National Comprehensive Cancer Network [1, 23])

\begin{tabular}{|c|c|c|}
\hline Rodzaj zakażenia & Zasady postępowania & Uwagi \\
\hline HSV/VZV & $\begin{array}{l}\text { Profilaktyka } \\
\text { Acyklowir dożylnie } 250 \mathrm{mg} / \mathrm{m}^{2} \\
\text { lub } 5 \mathrm{mg} / \mathrm{kg} \mathrm{mc} \text {. co } 12 \mathrm{~h} \\
\text { Acyklowir doustnie od } 2 \times 400 \mathrm{mg}(\mathrm{HSV}) \\
\text { do } 2 \times 800 \mathrm{mg} \text { (VZV) } \\
\text { Valacyklowir doustnie } 2 \times 500 \mathrm{mg}\end{array}$ & $\begin{array}{l}\text { Zalecana w czasie aktywnej terapii i przez ok. } 30 \text { dni po } \\
\text { jej zakończeniu: } \\
\text { - ostre białaczki (chorzy HSV-seropozytywni) } \\
\text { - chłoniaki, szpiczak plazmocytowy, przewlekła } \\
\text { białaczka limfocytowa } \\
\text { - analogi puryn } \\
\text { - alemtuzumab (do } 2 \text { miesięcy po zakończeniu terapii) } \\
\text { Profilaktyka VZV } \geq \text { rok po HSCT (GvHD, immunosu- } \\
\text { presja) }\end{array}$ \\
\hline HSV/VZV & Leczenie & \\
\hline Postać zlokalizowana & $\begin{array}{l}\text { Acyklowir dożylnie } 250 \mathrm{mg} / \mathrm{m}^{2} \\
\text { lub } 5 \mathrm{mg} / \mathrm{kg} \mathrm{mc} \text {. co } 8 \mathrm{~h} \\
\text { Acyklowir doustnie od } 5 \times 200 \mathrm{mg}(\mathrm{HSV}) \\
\text { do } 5 \times 800 \mathrm{mg}(\mathrm{VZV}) \\
\text { Valacyklowir doustnie od } 2 \times 500 \mathrm{mg} \\
(\text { HSV) do } 3 \times 1000 \mathrm{mg}(\mathrm{VZV}) \\
\text { Famcyklowir doustnie od } 2 \times 500 \mathrm{mg} \\
(\mathrm{HSV}) \text { do } 3 \times 500 \mathrm{mg}(\mathrm{VZV})\end{array}$ & Zalecany czas leczenia 7-10 dni \\
\hline $\begin{array}{l}\text { Postać rozsiana i/lub } \\
\text { narzadowa }\end{array}$ & $\begin{array}{l}\text { Acyklowir* dożylnie } 500 \mathrm{mg} / \mathrm{m}^{2} \\
\text { lub } 10 \mathrm{mg} / \mathrm{kg} \mathrm{mc} \text {. co } 8 \mathrm{~h}\end{array}$ & Zalecany czas leczenia 14-21 dni \\
\hline $\begin{array}{l}\text { HSV oporny } \\
\text { na leczenie }\end{array}$ & $\begin{array}{l}\text { Foskarnet** dożylnie } 60 \mathrm{mg} / \mathrm{kg} \mathrm{mc} \text {. } \\
\text { co } 12 \mathrm{~h}\end{array}$ & $\begin{array}{l}\text { Zalecany czas leczenia 7-21 dni lub do całkowitego } \\
\text { wyleczenia }\end{array}$ \\
\hline CMV & $\begin{array}{l}\text { Profilaktyka reaktywacji } \\
\text { Acyklowir* w dużych dawkach } \\
\text { Valacyklowir w dużych dawkach } \\
\text { Gancyklowir*** dożylnie } 5-6 \mathrm{mg} / \mathrm{kg} \mathrm{mc} \text {. } \\
\text { przez } 5 \text { dni w tygodniu }\end{array}$ & $\begin{array}{l}\text { Można rozważyć u chorych po allo-HSCT } \\
\text { Można rozważyć u chorych po allo-HSCT obciążonych } \\
\text { wysokim ryzykiem choroby CMV od czasu rekonstytucji } \\
\text { hematopoezy do + 100. dnia po HSCT } \\
\text { Profilaktyka farmakologiczna powinna być stosowana } \\
\text { równolegle z monitorowaniem antygenu pp65 lub } \\
\text { CMV DNA w krwi/osoczu }\end{array}$ \\
\hline
\end{tabular}

\begin{tabular}{|c|c|c|}
\hline CMV & $\begin{array}{l}\text { Leczenie wyprzedzające } \\
\text { Gancyklovir*** dożylnie } 5 \mathrm{mg} / \mathrm{kg} \mathrm{mc} \text {. } \\
\text { i.v. co } 12 \mathrm{~h} \geq 2 \text { tyg., do czasu uzyskania } \\
\text { ujemnych wyników badań } \\
\text { Valgancyklowir*** doustnie } 900 \mathrm{mg} \\
\text { co } 12 \mathrm{~h} \geq 2 \text { tyg., do czasu uzyskania } \\
\text { ujemnych wyników badań, rozważyć } \\
900 \mathrm{mg} \text { raz/d. przez kolejne } 7 \text { dni }\end{array}$ & $\begin{array}{l}\text { Zalecane u chorych po allo-HSCT } \\
\text { Można rozważyć u chorych po auto-HSCT obciążonych } \\
\text { wysokim ryzykiem choroby CMV oraz leczonych } \\
\text { alemtuzumabem } \\
\text { Valgancyklowir skuteczny u chorych leczonych } \\
\text { alemtuzumabem }\end{array}$ \\
\hline CMV & $\begin{array}{l}\text { Leczenie opornej infekcji } \\
\text { lub nietolerancja gancyklowiru } \\
\text { Foskawir** dożylnie } 90 \mathrm{mg} / \mathrm{kg} \mathrm{mc} \text {. } \\
\text { co } 12 \mathrm{~h} \\
\text { Leczenie skojarzone foskawirem** } \\
\text { i gancyklowirem } * * * \\
\text { Cydofowir**** dożylnie } 3-5 \mathrm{mg} / \\
/ \mathrm{kg} \mathrm{mc} \text {. raz/tydz. }\end{array}$ & $\begin{array}{l}\text { Oporność należy podejrzewać, jeżeli narasta liczba } \\
\text { kopii wirusa w badaniu ilościowym PCR } \\
\text { po } 2 \text { tygodniach leczenia } \\
\text { Czas leczenia } \geq 14 \mathrm{dni}\end{array}$ \\
\hline $\begin{array}{l}\text { Choroba wywołana } \\
\text { CMV (cytomegalia) }\end{array}$ & $\begin{array}{l}\text { Leczenie indukujące: gancyklowir }{ }^{* * *} \\
\text { Do czasu ustąpienia objawów, } \geq 4 \text { tyg. } \\
\text { dożylnie } 5 \mathrm{mg} / \mathrm{kg} \mathrm{mc} \text {. co } 12 \mathrm{~h} \text {. Dodat- } \\
\text { kowo duże dawki immunoglobulin } \\
\text { w śródmiąższowym zapaleniu płuc } \\
\text { Leczenie podtrzymujące: gancyklo- } \\
\text { wir*** } 5-6 \mathrm{mg} / \mathrm{kg} \mathrm{mc} \text {. przez } 5 \text { dni } \\
\text { w tygodniu }\end{array}$ & Czas leczenia 21-28 dni \\
\hline HHV-6 & $\begin{array}{l}\text { Profilaktyka niezalecana } \\
\text { Leczenie chorych z objawami: gancy- } \\
\text { klowir*** lub foskawir** w monoterapii } \\
\text { lub w skojarzeniu } \\
\text { Cydofowir**** w leczeniu II linii }\end{array}$ & \\
\hline
\end{tabular}

*Zalecone nawadnianie chorego w czasie leczenia dużymi dawkami acyklowiru; **nefrotoksyczność, zalecane nawadnianie chorego w trakcie leczenia; ***może powodować supresję szpiku; ****nefrotoksyczność, konieczne nawadnianie chorego i równoczesne stosowanie probenecidu; HSV (Herpes simplex virus) — wirus opryszczki pospolitej; VZV (Varicella zoster virus) - wirus ospy wietrznej i półpaśca; CMV (cytomegalovirus) - cytomegalowirus; PCR (polymerase chain reaction) - reakcja łańcuchowej polimerazy; HHV-6 (human herpesvirus-6) - wirus rumienia nagłego 6 
Tabela 10. Zasady leczenia zakażeń wirusami wywołującymi infekcje dróg oddechowych (na podstawie wytycznych European Conference on Infections in Leukemia oraz National Comprehensive Cancer Network [1, 26, 27])

Table 10. Principles of the treatment of viral respiratory infections (based on the guidelines of the European Conference on Infections in Leukemia and the National Comprehensive Cancer Network [1, 26, 27])

\begin{tabular}{|c|c|c|}
\hline Rodzaj zakażenia & Zasady postępowania & Uwagi \\
\hline RSV & $\begin{array}{l}\text { Profilaktyka farmakologiczna niezalecana } \\
\text { Leczenie: rybawiryna w postaci wziewnej } 2 \mathrm{~g} \\
\text { przez } 2 \mathrm{~h} \text { co } 8 \mathrm{~h}\end{array}$ & $\begin{array}{l}\text { W infekcji RSV dolnych dróg oddechowych } \\
\text { u chorych po allo-HSCT można dodatkowo podać } \\
\text { immunoglobuliny dożylnie }\end{array}$ \\
\hline \multirow[t]{3}{*}{ Grypa } & $\begin{array}{l}\text { Profilaktyka: szczepienie przed sezonem epi- } \\
\text { demicznym, nie wcześniej niż } 3 \text { miesiące po } \\
\text { allo-HSCT, a u chorych na ostre białaczki - po } \\
\text { zakończeniu intensywnej chemioterapii }\end{array}$ & $\begin{array}{l}\text { Zaleca się stosowanie inaktywowanej szczepionki } \\
\text { niezawierającej żywych wirusów }\end{array}$ \\
\hline & $\begin{array}{l}\text { Profilaktyka w przypadku ekspozycji: oseltamiwir } \\
\text { doustnie } 75 \mathrm{mg} \text { raz/d. przez } \geq 10 \mathrm{dni}\end{array}$ & $\begin{array}{l}\text { Rekomendowana do } 12 \text { miesięcy po allo-HSCT } \\
\text { (lub dłużej, jeżeli jest prowadzone leczenie im- } \\
\text { munosupresyjne), u chorych na ostre białaczki } \\
\text { podczas chemioterapii oraz u chorych z głębokimi } \\
\text { zaburzeniami odporności }\end{array}$ \\
\hline & $\begin{array}{l}\text { Leczenie: oseltamiwir doustnie } 75 \mathrm{mg} 2 \mathrm{razy} / \mathrm{d} \text {. } \\
\text { lub } 150 \mathrm{mg} 2 \mathrm{razy} / \mathrm{d} \text {. w przypadku ciężkiego prze- } \\
\text { biegu }\end{array}$ & $\begin{array}{l}\text { Lek należy zastosować w czasie pierwszych } 48 \text { h } \\
\text { od zachorowania, choć jego działanie może } \\
\text { przynieść korzystny efekt również w późniejszym } \\
\text { okresie }\end{array}$ \\
\hline Adenowirus & $\begin{array}{l}\text { Profilaktyka niezalecana } \\
\text { Leczenie chorych z objawami: cydofowir dożylnie } \\
3-5 \mathrm{mg} / \mathrm{kg} \text { mc. raz w tyg. przez 2-3 kolejne tyg. }\end{array}$ & \\
\hline
\end{tabular}

RSV (respiratory syncytial virus) - syncytialny wirus oddechowy; allo-HSCT (allogeneic hematopoietic stem cell transplantation) - przeszczepienie allogenicznych krwiotwórczych komórek macierzystych

wątroby typu B (HBV, hepatitis B virus) u chorych poddanych chemioterapii, immunoterapii przeciwciałami monoklonalnymi, leczeniu immunosupresyjnemu lub HSCT. Reaktywacja zakażenia HBV jest rozpoznawana $u$ chorych $z$ narastającą liczbą kopii wirusa lub ze wzrostem stężenia antygenu HBV w trakcie leczenia przeciwnowotworowego. O reaktywacji świadczy również ponowne pojawienie się HBV DNA we krwi chorego, u którego przed terapią wynik badania był ujemny [28]. Według piśmiennictwa reaktywację HBV stwierdza się u $12-24 \%$ chorych na chłoniaki nie-Hodgkina leczonych rytuksymabem skojarzonym $z$ chemioterapią obejmującą kortykosteroidy. U chorych leczonych przeciwnowotworowo $z$ laboratoryjnymi wykładnikami przebytej lub czynnej infekcji HBV należy rozważyć leczenie profilaktyczne (entekawir, lamiwudyna), które powinno być prowadzone pod nadzorem specjalisty chorób zakaźnych [28, 29].

\section{Podsumowanie}

Celem niniejszej pracy było ułatwienie Czytelnikowi wykorzystania w codziennej praktyce międzynarodowych rekomendacji dotyczących diagnostyki i leczenia powikłań infekcyjnych u chorych poddawanych chemioterapii lub HSCT $z$ powodu nowotworów hematologicznych. Przedstawione algorytmy wyboru i modyfikacji antybiotykotera- pii empirycznej w FN, kryteria rozpoznania oraz zasady leczenia profilaktycznego, empirycznego i celowanego inwazyjnych zakażeń grzybiczych, a także zasady postępowania w zakażeniach wirusowych mogą być pomocne w podejmowaniu indywidualnych decyzji terapeutycznych dotyczących poszczególnych chorych, jak również służyć opracowaniu racjonalnej polityki antybiotykowej w ośrodku onkohematologicznym.

\section{Piśmiennictwo}

1. Baden L.R., Bensinger W., Angarone M. i wsp. Prevention and treatment of cancer-related infections. NCCN Clinical Practice Guidelines in Oncology. Version 2.2014. Dostępne na: http://www.nccn.org/professionals/physician_gls/f_guidelines.asp. 12.01.2015.

2. Freifeld A.G., Bow E.J., Sepkowitz K.A. i wsp. Clinical practice guideline for the use of antimicrobial agents in neutropenic patients with cancer: 2010 update by the Infectious Diseases Society of America. Clin. Infect. Dis. 2011; 52: e56-e93.

3. Center for Disease Control. Guidelines for preventing opportunistic infections among hematopoietic stem cell transplant recipients. Recommendations of CDC, the Infectious Disease Society of America, and the American Society of Blood and Marrow Transplantation. Cytotherapy 2001; 3: 41-54.

4. Mikulska M., Viscoli C., Orasch C. i wsp. Aetiology and resistance in bacteraemias among adult and paediatric haematology and cancer patients. J. Infect. 2014; 68: 321-331.

5. Gafter-Gvili A., Fraser A., Paul M. i wsp. Antibiotic prophylaxis for bacterial infections in afebrile neutropenic patients following chemotherapy. Cochrane Database Syst. Rev. 2012; 18: CD004386. 
6. Klastersky J., Paesmans M., Rubenstein E.B. i wsp. The Multinational Association for Supportive Care in Cancer risk index: a multinational scoring system for identifying low-risk febrile neutropenic cancer patients. J. Clin. Oncol. 2000; 18: 3038-3051.

7. Averbuch D., Orasch C., Cordonnier C. i wsp. European guidelines for empirical antibacterial therapy for febrile neutropenic patients in the era of growing resistance: summary of the 2011 4th European Conference on Infections in Leukemia. Haematologica 2013; 98: 1826-1835.

8. Averbuch D., Cordonnier C., Livermore D.M., i wsp. Targeted therapy against multi-resistant bacteria in leukemic and hematopoietic stem cell transplant recipients: guidelines of the 4th European Conference on Infections in Leukemia (ECIL-4, 2011). Haematologica 2013; 98: 1836-1847.

9. Biliński P., Seferyńska I., Warzocha K. Diagnostyka i leczenie układowych zakażeń grzybiczych w onkohematologii. Onkol. Prakt. Klin. 2008; 4: 15-24.

10. Butrym A., Zywar K., Dzietczenia J. i wsp. Inwazyjne zakażenia grzybicze u pacjentów z nowotworami hematologicznymi. Mikologia Lekarska 2011; 18: 47-53.

11. Dzierżanowska D. Leczenie zakażeń szpitalnych. $\alpha$-medica press, Bielsko-Biała 2007.

12. Pagano L., Caira M., Valentini C.G. i wsp. Current therapeutic approaches to fungal infections in immunocompromised hematological patients. Blood Rev. 2010; 24: 51-61.

13. Pagano L., Akova M., Dimopoulos G. i wsp. Risk assessment and prognostic factors for mould-related diseases in immunocompromised patients. J. Antimicrob. Chemother. 2011; 66 (supl. 1): i5-i14.

14. Maertens J., Marchetti O., Herbrecht R. i wsp. European guidelines for antifungal management in leukemia and hematopoietic stem cell transplant recipients: summary of the ECIL $3-2009$ update. Bone Marrow Transplant. 2011; 46: 709-718.

15. De Pauw B., Walsh T.J., Donnelly J.P. i wsp. Revised definitions of invasive fungal disease from the European Organization for Research and Treatment of Cancer/Invasive Fungal Infections Cooperative Group and the National Institute of Allergy and Infectious Diseases Mycoses Study Group (EORTC/MSG) Consensus Group. Clin. Infect. Dis. 2008; 46: 1813-1821.

16. Arendrup M.C., Bille J., Dannaoui E. i wsp. ECIL-3 classical diagnostic procedures for the diagnosis of invasive fungal diseases in patients with leukaemia. Bone Marrow Transplant. 2012; 47: 1030-1045.

17. Marchetti O., Lamoth F., Mikulska M. i wsp. ECIL recommendations for the use of biological markers for the diagnosis of invasive fungal diseases in leukemic patients and hematopoietic SCT recipients. Bone Marrow Transplant. 2012; 47: 846-854.
18. Castagna L., Bramanti S., Sarina B. i wsp. ECIL 3-2009 update guidelines for antifungal management. Bone Marrow Transplant. 2012; 47: 866.

19. Cordonnier C., Pautas C., Maury S. i wsp. Empirical versus preemptive antifungal therapy for high-risk, febrile, neutropenic patients: a randomized, controlled trial. Clin. Infect. Dis. 2009; 48: 1042-1051.

20. Maertens J., Groll A.H., Cordonnier C. i wsp. Treatment and timing in invasive mould disease. J. Antimicrob. Chemother. 2011; 66: i37-i43.

21. Groll A.H., Castagnola E., Cesaro S. i wsp. Fourth European Conference on Infections in Leukaemia (ECIL-4): guidelines for diagnosis, prevention, and treatment of invasive fungal diseases in paediatric patients with cancer or allogeneic haemopoietic stem cell transplantation. Lancet Oncol. 2014; 15: e327-e340.

22. Mousset S., Buchheidt D., Heinz W. i wsp. Treatment of invasive fungal infections in cancer patients-updated recommendations of the Infectious Diseases Working Party (AGIHO) of the German Society of Hematology and Oncology (DGHO). Ann. Hematol. 2014; 93: 13-32.

23. Ljungman P., de la Camara R., Cordonnier C. i wsp. Management of CMV, HHV-6, HHV-7 and Kaposi-sarcoma herpesvirus (HHV-8) infections in patients with hematological malignancies and after SCT. Bone Marrow Transplant. 2008; 42: 227-240.

24. Ljungman P., Hakki M., Boeckh M. Cytomegalowvirus in hematopoietic stem cell transplant recipients. Hematol. Oncol. Clin. North Am. 2011; 25: 151-169.

25. Styczyński J., Gil L., Tridello G. i wsp. Response to rituximab-based therapy and risk factor analysis in Epstein-Barr virus-related lymphoproliferative disorder after hematopoietic stem cell transplant in children and adults: a study from the Infectious Diseases Working Party of the European Group for Blood and Marrow Transplantation. Clin. Infect. Dis. 2013; 57: 794-802.

26. Hirsch H.H., Martino R., Ward K.N. i wsp. Fourth European Conference on Infections in Leukaemia (ECIL-4): guidelines for diagnosis and treatment of human respiratory syncytial virus, parainfluenza virus, metapneumovirus, rhinovirus, and coronavirus. Clin. Infect. Dis. 2013; 56: 258-266.

27. Engelhard D., Mohty B., de la Camara R. i wsp.; on behalf of ECIL, a joint venture of EBMT, EORTC, ICHS, and ELN. European guidelines for prevention and management of influenza in hematopoietic stem cell transplantation and leukemia patients: summary of ECIL-4 (2011). Trans. Infect. Dis. 2013; 15: 219-232.

28. Hwang J.P. Lok A.S. Management of patients with hepatitis B who require immunosuppressive therapy. Nat. Rev. Gastroenterol. Hepatol. 2014; 11: 209-219.

29. Kalinka-Warzocha E. Leczenie chorych z chłoniakami i współistniejącym zakażeniem HCV, HBV lub HIV. Hematologia 2010; 1: 296-305. 